\title{
Flora do Espírito Santo: Aristolochiaceae
}

\author{
Flora of Espírito Santo: Aristolochiaceae
}

Joelcio Freitas ${ }^{1,2}$ \& Anderson Alves-Araújo ${ }^{1}$

\begin{abstract}
Resumo
Aristolochiaceae Juss. (Piperales) é constituída por aproximadamente 600 espécies, das quais 550 pertencem ao gênero Aristolochia, sendo o Brasil representado por 92 espécies, 39 delas na Mata Atlântica. O presente trabalho tem como objetivo documentar a diversidade taxonômica de Aristolochiaceae no estado do Espírito Santo (ES). Expedições para coleta de material botânico foram realizadas de fevereiro/2014 a agosto/2015. As principais coleções do estado (CVRD, MBML e VIES) e de estados vizinhos (RB, R, HUEFS, ALCB) foram consultadas para análise de espécimes, além de coleções online (C, CEPEC, F, HRCB, K, M, MBM, MPU, P, S e SP). Um total de 20 espécies foi registrado para o estado: Aristolochia arcuata, A. assisii, A. bahiensis, A. chamissonis, A. cymbifera, A. cynanchifolia, A. elegans, A. gigantea, A. aff. gigantea, A. gracilipedunculata, A. hypoglauca, A. labiata, A. longispathulata, A. melastoma, A. nevesarmondiana, A. pubescens, A. subglobosa, A. tamnifolia, A. trilobata e A. zebrina. Uma espécie enquadra-se na categoria Vulnerável (VU), oito na categoria Em Perigo (EN) e quatro em Criticamente Ameaçada (CR). O número de espécies encontradas acrescenta 9 táxons na lista de espécies conhecidas para o ES (aumento de 81\%), demonstrando a importância de coletas para o Espírito Santo e conhecimento de sua flora.
\end{abstract}

Palavras-chave: Mata Atlântica, Piperales, taxonomia.

\begin{abstract}
Aristolochiaceae Juss. (Piperales) has around 600 species of which 550 belong to Aristolochia. In Brazil, Aristolochia is represented by 92 species, 39 of them can be found in the Atlantic Forest. This study aimed to investigate the taxonomic diversity of Aristolochiaceae from Espírito Santo state (ES). Thus, fieldwork was performed from February/2014 to August/2015 and collections were visited and/or consulted (ALCB, C, CEPEC, CVRD, F, HRCB, HUEFS, K, M, MBM, MBML, MPU, P, S, SP, R, RB, and VIES). Specialized literature and nomenclatural types were consulted to determine specific identity of the taxa. A total of 20 species is recorded for ES: Aristolochia arcuata, A. assisii, A. bahiensis, A. chamissonis, A. cymbifera, A. cynanchifolia, A. elegans, A. gigantea, A. aff. gigantea, A. gracilipedunculata, A. hypoglauca, A. labiata, A. longispathulata, A. melastoma, A. nevesarmondiana, A. pubescens, A. subglobosa, A. tamnifolia, A. trilobata, and A. zebrina. One species was assigned as Vulnerable (VU), eight as Endangered (EN), and four as Critically Threatened (CR). Compared to the previously listed for ES and after nomenclatural updates, nine taxa (about $81 \%$ ) are new records for the State. Results demonstrated the importance of extensive sampling and contributed for a better understanding of ES flora. Key words: Atlantic forest, Piperales, taxonomy.
\end{abstract}

\section{Introdução}

No Brasil, a Mata Atlântica é o terceiro maior bioma em extensão, depois da Amazônia e do Cerrado. Suas formações vegetais e ecossistemas associados cobriam originalmente uma área total de $1.227 .600 \mathrm{~km}^{2}$, correspondendo a aproximados $16 \%$ do território brasileiro (Conservation International do Brasil et al. 2000). O estado do Espírito Santo está localizado, em quase toda sua totalidade, no Corredor Central da Mata Atlântica, sendo esta uma das áreas mais importantes para a conservação da biodiversidade do planeta (Brasil 2006).

\footnotetext{
${ }^{1}$ Universidade Federal do Espírito Santo-UFES, Centro Universitário Norte do Espírito Santo-CEUNES, Depto. Ciências Agrárias e Biológicas, Lab. Sistemática e Genética Vegetal, Prog. Pós-graduação em Biodiversidade Tropical, Rod. BR-101 Norte, Km 60, Bairro Litorâneo, 29932-540, São Mateus, ES, Brasil.

22Autor para correspondência: joelciofr@gmail.com
} 
As fitofisionomias encontradas no Espírito Santo são, de acordo com Garbin et al. (2017), Floresta Ombrófila Densa (que inclui os Tabuleiros costeiros), Floresta Ombrófila Aberta, Floresta Estacional Semidecidual, Savanas, Formações Pioneiras (Restingas) e Refúgios Ecológicos. A degradação ambiental sofrida por essas formações foi muito acentuada ao longo dos anos, sendo que atualmente restam apenas $12,02 \%$ de sua cobertura total original (Fundação SOS Mata Atlântica \& INPE 2014). Contudo, ele representa um dos principais centros de endemismo para plantas (Martini et al. 2007).

Das aproximadas 32.000 espécies de Angiospermas atualmente aceitas para o Brasil, mais de 15.000 têm ocorrência para o domínio da Mata Atlântica. O estado do Espírito Santo está representado por 6.364 espécies, pertencentes a 1.390 gêneros e 180 famílias (Dutra et al. 2015), dentre elas, Aristolochiaceae. Esta família pertence a ordem Piperales (APG IV 2016), sendo representada pelos gêneros Aristolochia L., Asarum L., Saruma Oliv. e Thotthea Rottb., somando aproximadamente 600 espécies (González 1990, 2012). Aristolochia é o mais diverso, com cerca de 550 espécies (González 2012), sendo o Haiti e o Brasil seus principais centros de diversidade (González 2000). No Brasil, a família está representada apenas por Aristolochia com 93 espécies, destas 39 são registradas na Mata Atlântica (BFG 2015; Freitas et al. 2017).

A família apresenta características morfológicas peculiares, principalmente no que diz respeito ao seu mecanismo de polinização. Tão interessante quanto, são as suas propriedades medicinais, com o qual inclusive, dá-se o nome à família: aristos $=$ melhor lochios $=$ descarga uterina pós-parto ou expulsão da placenta (Hoehne 1942). Inúmeras espécies de Aristolochia, conhecidas popularmente como 'papo-de-peru', 'cipó-milhomens', ou simplesmente 'milome', são utilizadas para tratar males de estômago e intestino (Hoehne 1942).

Dentre os estudos taxonômicos realizados nas últimas décadas sobre a família na Mata Atlântica, destacam-se os estudos regionais realizados para a região Nordeste (Araújo 2013a, 2013b; Abreu \& Giulietti 2016a) e Sul do Brasil (Nascimento 2008), para o estado de São Paulo (Capellari 1991), além de descrições de novos táxons (González 1998, 2000; Araújo \& Alves 2013; Abreu \& Giulietti 2016b; Freitas et al. 2017). Para o Espírito Santo, os trabalhos taxonômicos com a família são bastante recentes (Gonzalez 2011; Freitas et al. 2013a,b; Freitas et al. 2014; Freitas et al. 2016) e evidenciam que a riqueza de espécies de Aristolochiaceae no estado pode estar subestimada.

Tendo em vista a riqueza de espécies já reconhecida para a Mata Atlântica e a pouca quantidade da informação acerca das Aristolochiaceae no Espírito Santo, o presente trabalho visa ampliar o conhecimento taxonômico da família para o estado, atualizar os estados de conservação e a distribuição geográfica das espécies. Informações morfológicas e ecológicas sobre o gênero no Brasil são fornecidas com o objetivo de facilitar a determinação a partir de suas características peculiares.

\section{Material e Métodos}

Expedições de campo foram realizadas no período de fevereiro/2014 a agosto/2015 para coleta de material botânico. Espécimes de Aristolochia das principais coleções do estado (CVRD, MBML e VIES) e estados vizinhos (CEPEC, RB, R, HUEFS, ALCB) foram analisados, além de imagens de espécimes adicionais e tipos depositados nas coleções online $\mathrm{C}, \mathrm{F}, \mathrm{HRCB}$, K, M, MBM, MPU, P, S e SP (acrônimos de acordo com Thiers, continuamente atualizado). Amostras de flores e/ou frutos foram retiradas e mantidas em álcool a 70\%, para identificação e confecção das descrições e ilustrações dos táxons. O material obtido foi herborizado de acordo com as técnicas propostas por Bridson \& Forman (1998). Para cada coleta, foram anotadas as coordenadas geográficas, através de Sistema de Posicionamento Global (GPS). O material coletado foi depositado no Herbário VIES com duplicatas enviadas para o Herbário do Instituto Nacional da Mata Atlântica (MBML) e Jardim Botânico do Rio de Janeiro (RB). Amostras de algumas espécies foram colhidas para compor uma coleção viva no INMA, assim como já vem sendo realizada com outras famílias na instituição (e.g., Marantaceae, Bromeliaceae, Orchidaceae).

A identificação das espécies tomou por base a utilização das principais chaves de identificação disponíveis na literatura (Hoehne 1927, 1942; Ahumada 1967; González 1990; Capellari Jr. 1991; Nascimento 2008; Araújo 2013a) e da confirmação nas descrições originais das espécies. Dados morfológicos referentes às espécies foram utilizados para confecção das chaves de identificação, descrições e ilustrações. A complementação das descrições com materiais 
de outros estados e com bibliografia (Hoehne 1942; Capellari Jr. 1991; Nascimento 2008; Araújo 2013a) foi realizada quando os espécimes do ES não apresentavam todas as fenofases disponíveis. A terminologia morfológica foi baseada em Rizzini (1965); Harris \& Harris (2001); Hickey (1973); e González (1990, 1994). Para composição das ilustrações, foi utilizado estereomicroscópio acoplado à câmara clara.

Para a análise do estado de conservação regional das espécies foram utilizados os critérios da União Internacional para Conservação da Natureza - IUCN (2010, 2015), sendo a Extensão de ocorrência (EOO) e Área de ocupação (AOO) calculadas com o Geospatial Conservation Assesment Tool (GeoCat) (Bachman et al. 2011). Os dados obtidos das coletas realizadas em campo e análise de coleções foram utilizados como base para responder aos critérios analisados. Para os mapas de distribuição geográfica das espécies utilizouse o software Quantum-GIS 2.12 (Quantum Gis Development Team 2015). Foram incluídas nos mapas também as localidades nas quais foi observada a ocorrência de indivíduos das espécies, e que não foram coletados por estarem estéreis.

\section{Resultados e Discussão}

\section{Hábito}

$$
\text { Aspectos morfológicos }
$$

O gênero Aristolochia no ES está representado predominantemente por espécies com hábito trepador (Fig. 1a), comum inclusive para a maioria das espécies da família. A única espécie que se apresenta como erva ereta é Aristolochia assisii J.Freitas, Lírio \& F.González (Fig. 1b), com até $40 \mathrm{~cm}$ de altura, que cresce, principalmente, sobre ambientes rochosos. Aristolochia assisii possui indivíduos adultos com hábito herbáceo e um florescimento rápido, o que pode indicar um caráter relacionado à economia de água, já que a espécie vive em ambientes xéricos. A cada nova floração o indivíduo cessa a parte vegetativa e inicia um novo rebroto para a próxima floração, a partir do xilopódio presente na planta. O comum para o gênero é um crescimento vegetativo contínuo por alguns anos até o florescimento (Freitas et al. 2014). Porém, após o mesmo, a parte vegetativa da planta não cessa o crescimento até sua próxima floração.

O hábito herbáceo terrestre está presente em algumas outras espécies de Aristolochia ocorrente no Brasil, como $A$. smilacina Duch., que ocorre em ambientes rochosos, principalmente no estado de
Minas Gerais e que, frequentemente, perde suas folhas durante períodos de incêndios ou épocas de estiagem prolongada, rebrotando após este período a partir das reservas contidas em seu xilopódio (Hoehne 1942).

\section{Caule e xilopódio}

Caules suberosos frequentemente são encontrados em algumas espécies adultas após vários anos (Fig. 1c), onde quanto maior a idade da planta, maior será o diâmetro deste caule. Para alguns grupos, como a subsérie Anthocaulicae, esse caule suberoso é importante para a floração das espécies (Fig. 1d), uma vez que é nele que as inflorescências em racemo surgem na época da floração (Hoehne 1942). Porém, em indivíduos mais jovens, onde esse caule ainda não está bem desenvolvido, pode ocorrer o florescimento nas gemas foliares ou até mesmo no meio dos ramos, em flores isoladas (Freitas, observação pessoal).

O florescimento nesses caules é comum, já retratado por Hoehne (1942), e acredita-se ser característica adaptativa do grupo que apresenta flores dispostas em inflorescências multifloras, uma vez que estas espécies vivem em ambientes com disponibilidade menor de luz que os demais representantes do gênero. Para Hoehne (1942), o florescimento no caule na base da planta teria relação com os polinizadores que vivem no subbosque.

Quando ocorre um corte da parte vegetativa da planta, e permanecendo o caule suberoso, não é raro surgir o rebroto de inúmeros ramos a partir dele (Freitas, observação pessoal). Essa característica pode ser considerada importante no aspecto de regeneração em ambientes impactados, uma vez que, como as espécies do gênero são mais comumente encontradas em bordas de floresta, tornam-se mais suscetíveis a interferências antrópicas por supressão da vegetação.

O xilopódio é um tubérculo lenhoso (Fig. 2a), gemífero, presente em certas plantas adaptadas ao período de seca anual, e que armazena água e nutrientes nesse período, possibilitando o brotamento de novos ramos ao fim do mesmo (Hoehne 1942). Essa estrutura é bem desenvolvida em inúmeras espécies de Aristolochia (Hoehne 1942; Capellari 1991). Na maioria dos táxons, a estrutura é maior em indivíduos mais velhos, porém é necessário que seja feita a escavação no entorno da planta para sua observação, pois o xilopódio encontra-se numa certa profundidade (Capellari 1991). 


\section{Folhas, pseudoestípulas e indumento}

As folhas de Aristolochia apresentam formato variado, porém o mais comum são os formatos oval (Fig. 2b) a cordado, e raramente lobado. As pseudoestípulas (Fig. 2c), embora semelhantes morfologicamente às estípulas encontradas em espécies de Passifloraceae, têm origem diferente e trata-se de profilos modificados (Hoehne 1942) que conferem proteção à base do pecíolo.

Vegetativamente, quando as pseudoestípulas estão presentes, as mesmas facilitam o reconhecimento do gênero em campo. A ausência delas pode dificultar este processo, sendo as espécies frequentemente confundidas com as de
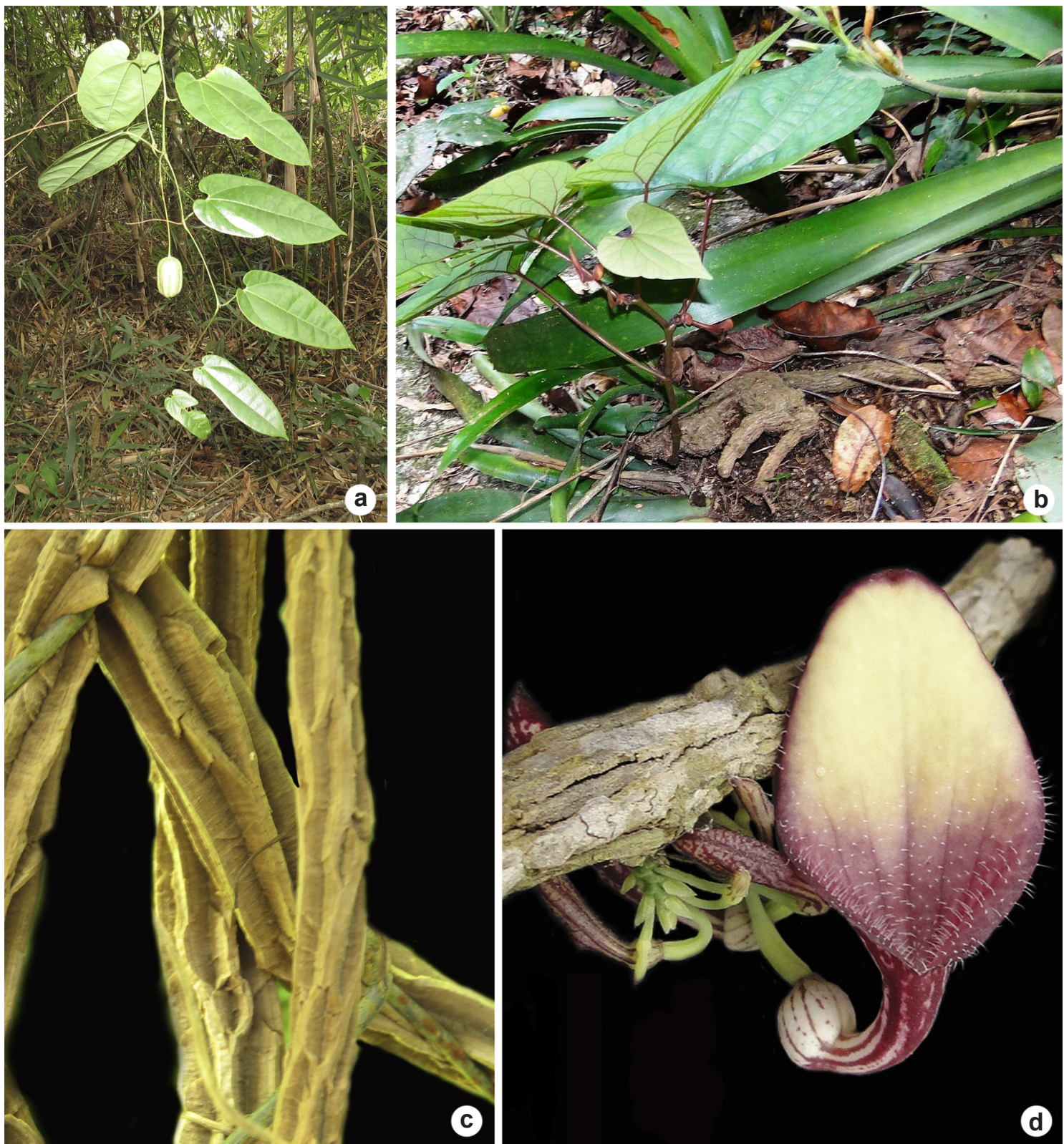

Figura 1 - a,b. hábitos de Aristolochia - a. Aristolochia cynanchifolia - trepadeira herbácea; b. Aristolochia assisii - herbáceo terrestre. c,d. caule suberoso em Aristolochia - c. desenvolvido em indivíduos mais velhos; d. ocorrência de racemo no caule.

Figure 1 - a,b. Aristolochia habit - a. Aristolochia cynanchifolia - herbaceous vine; b. Aristolochia assisii - terrestrial and herbaceous. c,d. corky stems in Aristolochia - c. developed in mature individuals; d. cauliflorous racemes. 
outras famílias, como as Menispermaceae, por exemplo.

O padrão de venação primária basal das folhas apresenta uma nervura principal e duas ou quatro secundárias partindo da base. Do par externo dessas nervuras secundárias, partem ainda mais uma nervura de cada. Esse padrão é uma característica diagnóstica para as espécies. Para as espécies capixabas, a venação mais observada foi de 5(7) (Fig. 2d,e) e 3(5) (Fig. 2f,g).

\section{Inflorescências}

As espécies de Aristolochia do Brasil apresentam alguns tipos distintos de disposição das flores: inflorescência em tirsos (Fig. 3a), racemos com entrenós das flores $<1 \mathrm{~mm}$ (Fig. $3 \mathrm{~b}$ ), racemos com entrenós das flores $>5 \mathrm{~mm}$
(Fig. 3c), ripídios (Fig. 3d) e unifloras (Fig. 3e). O padrão das inflorescências está relacionado diretamente aos grupos com o qual as espécies se enquadram. Em Aristolochia série Thyrsicae F. González o padrão das flores é a disposição em tirsos ou ripídios. A base do pedúnculo possui zona basal de abscisão, e cada flor na inflorescência está oposta à uma bractea. Em Aristolochia série Hexandrae F. González há a subdivisão em duas subséries: as espécies de Aristolochia subsérie Hexandrae F. González apresentam flores isoladas, ebracteadas nas axilas foliares e, ocasionalmente, aparecem em racemos com entrenós das flores $>5 \mathrm{~mm}$. Os representantes de Aristolochia subsérie Anthocaulicae F. González possuem inflorescências em racemos, com flores subtendidas por brácteas, e entrenós das flores
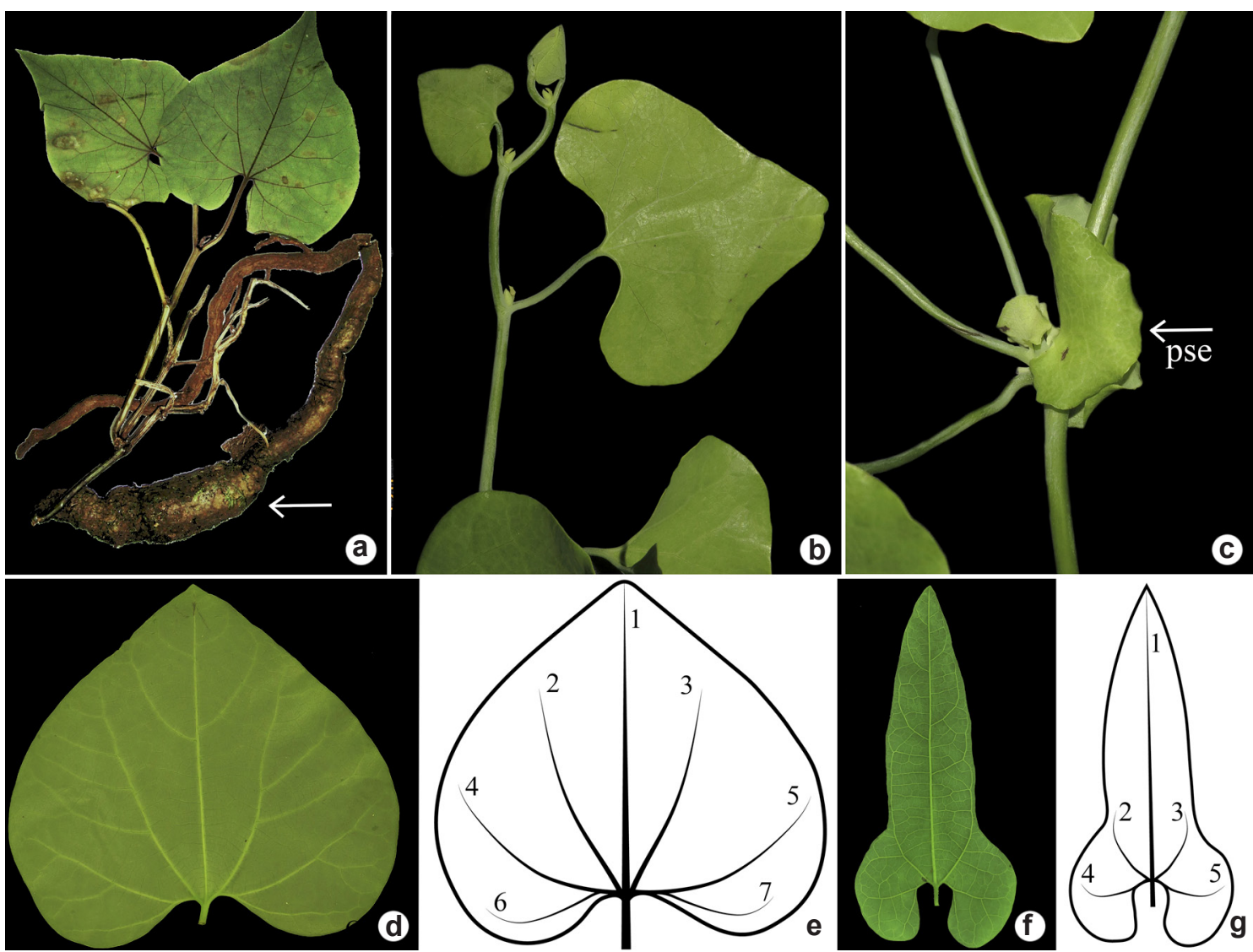

Figura 2 - a. Aristolochia assisi - Xilopódio (seta). b,c. estruturas foliares em Aristolochia - b. visão geral de um ramo jovem em crescimento; c. seta indica a pseudoestípula (pse). d-g. padrão de venação primária basal de duas espécies de Aristolochia - d,e. Aristolochia gigantea - onde o padrão de nervuras é de 5(7); f,g. Aristolochia pubescens - com padrão de 3(5).

Figure 2 - a. Aristolochia assisi - Xylopodium (arrow). b,c. leaf structures in Aristolochia - b. overview of a growing young branch; c. pseudostipule (pse) (arrows). d-g. basal primary veins pattern of two species of Aristolochia-d,e. Aristolochia gigantea - venation pattern 5(7); f,g. Aristolochia pubescens - venation pattern 3(5). 
$<1 \mathrm{~mm}$. Ocasionalmente, como já mencionado, as flores podem se apresentar isoladas em indivíduos mais jovens. As espécies do ES possuem representantes de todos os três grupos, quatro espécies de $A$. subsérie Anthocaulicae, uma de $A$. série Thyrsicae (A. melastoma) e as demais de $A$. subsérie Hexandrae.

\section{Flores}

As flores de Aristolochia são monoclamídeas, gamossépalas e a arquitetura floral compreende três estruturas principais: utrículo, tubo e limbo (Fig. 3f,g). O utrículo é a parte basal da flor (Fig. 4a),e abriga o ginostêmio, estrutura caracterizada pela fusão do androceu e gineceu (Fig. 4b[1]). O utrículo
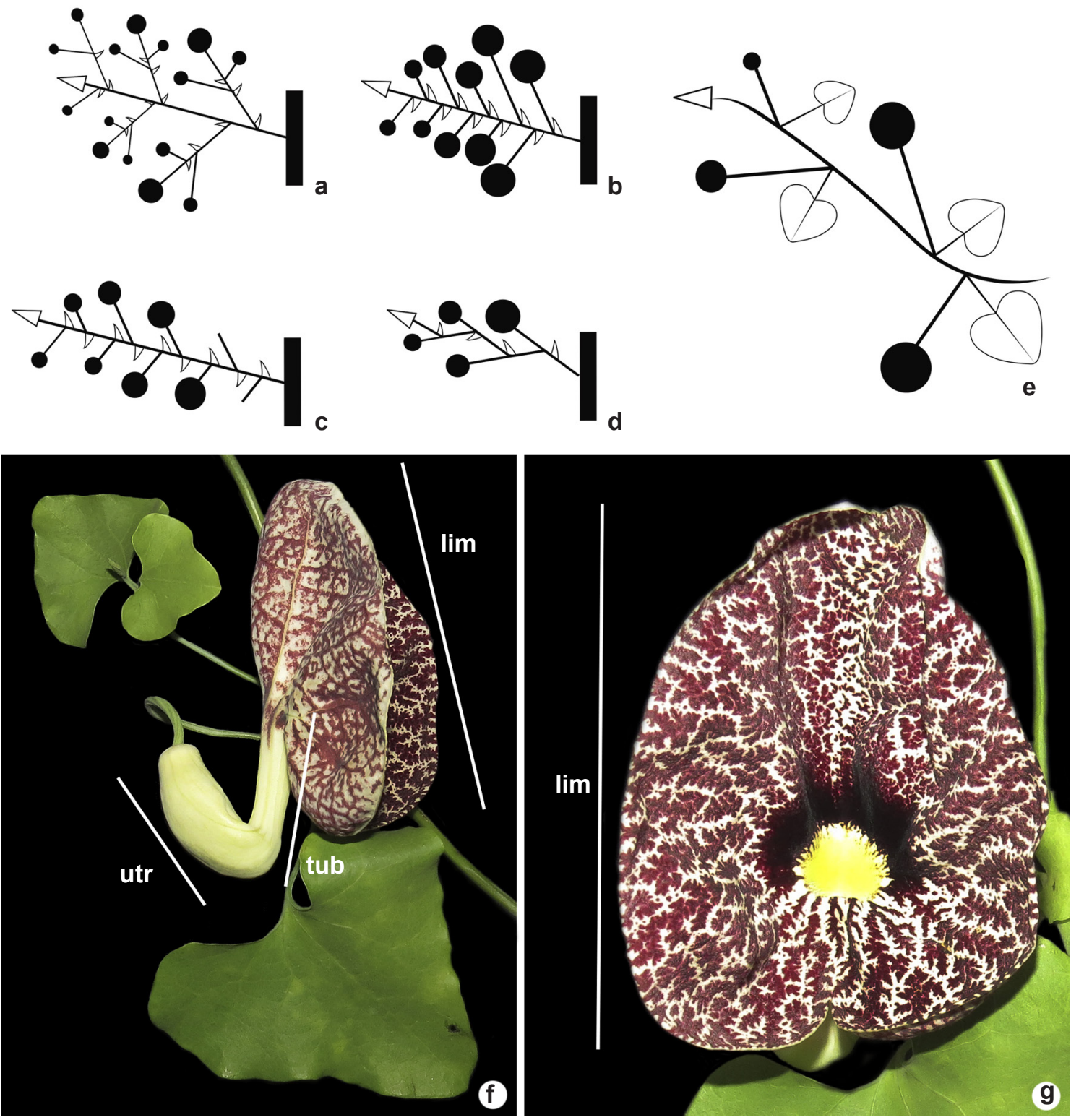

Figura 3 - a-e. inflorescências em Aristolochia - a. tirsos; b. racemos com entrenós das flores $<1$ mm compr; c. racemos com entrenós das flores $>5$ mm compr; d. ripídios; e. unifloras (Modificado de González, 1990). f,g. estruturas florais em Aristolochia - f. flor em visão lateral; g. frontal (lim = limbo; tub = tubo; utr = utrículo).

Figure 3 - a-e. inflorescences in Aristolochia - a. thyrsi; b. racemes with internodes $<1 \mathrm{~mm}$ long; c. racemes with internodes $>5 \mathrm{~mm}$ long; d. rhipidia; e. solitary flowers (uniflorous) (Modified from González, 1990). f,g. floral structures in Aristolochia - f. flower side; g. frontal views $(\lim =\operatorname{limb} ;$ tub $=$ tube; $u$ tr $=$ utricle $)$. 
além de abrigar a estrutura reprodutiva da planta, ainda assume a função de 'aprisionar' os insetos durante o processo de polinização.

O tubo é uma estrutura alongada que liga o exterior com as estruturas reprodutivas da flor. Sua principal função é a condução dos polinizadores para dentro do utrículo, onde, frequentemente, apresenta uma extensão chamada de siringe (Fig. $4 \mathrm{~b}[2])$, que nada mais é do que um prolongamento deste tubo, que facilita a entrada dos insetos, também dificultando a sua saída. O tubo internamente é ornado com vários tricomas rígidos, voltados para dentro, que também têm a finalidade de favorecer o acesso dos polinizadores. O limbo é a estrutura mais ornamentada das flores. Geralmente possui uma coloração diferenciada, ornada com tricomas (apêndices epidérmicos dispersos, delgados $\mathrm{e}<2 \mathrm{~mm}$ de comprimento) ou fímbrias (apêndices epidérmicos geralmente na borda do limbo, espessos e $>5 \mathrm{~mm}$ de comprimento). Além disso, pode-se diferenciar quanto ao número de lábios que compõe o limbo: unilabiadas ou bilabiadas (Capellari Jr. 1991). O tamanho do limbo também apresenta uma variação grande entre as espécies, sendo que a maioria das
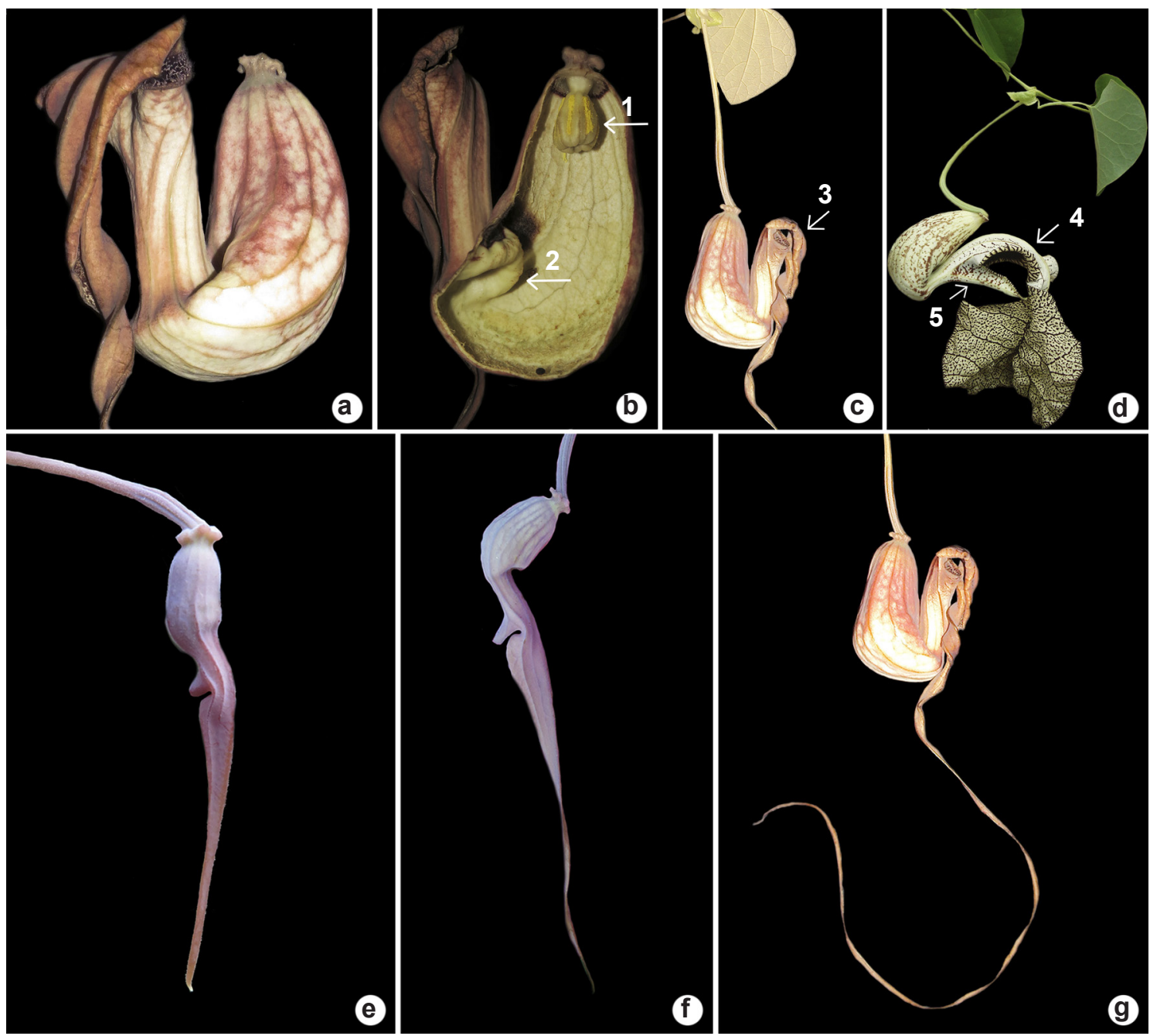

Figura 4 - a,b. utrículo, ginostêmio e siringe - a. visão geral da flor; b. corte no utrículo indicando o ginostêmio (1) e a siringe (2). c,d. limbo em Aristolochia - c. seta indica o limbo unilabiado (3); d. setas indicam limbo bilabiado [lábio superior (4) e inferior (5)]. e-g. desenvolvimento floral em Aristolochia - e. botão com formação retilínia; f. curvatura parcial; g. curvatura total com a flor já desenvolvida.

Figure 4 - a,b. utricle, gynostemium, and syrinx - a. flower overview; b. sectioned utricle indicating gynostemium (1) and syrinx (2). c,d. limb in Aristolochia - c. unilabiate limb (arrow) (3); d. bilabiate limb (arrows) [upper (4) and lower lip (5)]. e-g. floral development in Aristolochia - e. erect bud; f. partially curved; g. totally curved in mature flower. 
espécies no ES apresenta limbos unilabiados (Fig. 4c) e de comprimento 1-2 cm (como em $A$. bahiensis e $A$. nevesarmondiana) ou bem maiores, variando de 28 $29 \mathrm{~cm}$ (como em A. gigantea). Apenas Aristolochia cymbifera e A. labiata apresentam uma formação do limbo bilabiadas, ou seja, formando duas partes distintas, o lábio superior e inferior (Fig. 4d).

A coloração das flores é, sobretudo, chamativa no limbo, sendo que as cores apresentam pouca variação, com o roxo e o vermelho escuro quase sempre presentes, além de algumas tonalidades de verde e amarelo. O desenvolvimento das flores se dá através de uma curvatura pronunciada durante a antese. $\mathrm{O}$ perianto no início da formação floral se apresenta retilínio (Fig. 4e) e, à medida que ocorre o seu desenvolvimento, a angulação da flor aumenta próxima à junção utrículo-tubo (Fig. 4f,g), formando um ângulo de aproximadamente $90^{\circ}$ entre ambas as estruturas. Essa curvatura é responsável pelo aparecimento da siringe em algumas espécies. Essa modificação gradual do perianto já foi reportada para algumas espécies (Costa \& Hime 1981; González \& Stevenson 2000; Freitas et al. 2013a, 2014).

\section{Protoginia e polinização}

Uma característica importante em relação à polinização é o fato do gênero Aristolochia ser protogínico (Capellari Jr. 1991), com o amadurecimento prévio do gineceu em relação ao androceu. Ao abrir a flor, tanto o interior do tubo quanto as paredes internas do utrículo estão repletos de tricomas rígidos (Fig. 5a) que facilitam a entrada do polinizador. Neste momento, os lobos estigmáticos já estão receptivos (Fig. 5b) a receber os grãos de pólen advindos de polinizadores que entrarem na flor. Caso um inseto entre na flor portando grãos de pólen retirados de outra flor, o processo de polinização provavelmente se concretizará. Caso contrário, o inseto ficará 'aprisionado' no interior do utrículo por horas ou até dias, até que o androceu amadureça e libere os grãos de pólen (Fig. 5c) (que serão levados pelos insetos). Quando ocorre essa liberação do pólen, os tricomas antes rígidos, tornam-se frouxos (Fig. 5d) e, com isso, o polinizador consegue sair da flor carregando os grãos de pólen para outra flor.

Os polinizadores são basicamente do gênero Drosophila Fallén, 1823 (Capellari Jr. 1991), porém carecem ainda de estudos aprofundados para a flora brasileira. Para as flores que são menores e desprovidas de odores, a exemplo de A. longispathulata, os insetos têm tamanho reduzido (ca. $2 \mathrm{~mm}$ aproximadamente) (Fig. 5e,f), e são atraídos sobretudo pela coloração ou odores pouco perceptíveis. Nas flores maiores (e.g., A. cymbifera) geralmente os agentes polinizadores são as moscas varejeiras, que são atraídas pelos odores de material em putrefação que as flores exalam (Capellari Jr. 1991).

\section{Frutos e sementes}

Os frutos e sementes exibem geralmente caracteres diagnósticos para algumas espécies. Os frutos de Aristolochia (Fig. 6a) são do tipo cápsula septicida, onde a abertura se dá pela linha que une os carpelos. $\mathrm{O}$ ápice do fruto permanece fundido e a base se abre, formando uma espécie de cesta, onde as sementes ficam depositadas (Fig. 6b).

A veia média, que é a linha contínua que parte da base do pedúnculo até o ápice dos mericarpos, normalmente está presente na parte dorsal de cada um dos septos do fruto (mericarpo). Essa linha pode ser proeminente (1 a $3 \mathrm{~mm}$ ) (Fig. 6c) ou não (Fig. 6d), e é um caráter diagnóstico para algumas espécies. No ápice do fruto há normalmente a presença de uma estrutura chamada de rostro, que se apresenta normalmente com um tamanho de um a três milímetros (como em A. hypoglauca) (Fig. 6e) até 1,2 cm (como em $A$. assisii) (Fig. 6f).

As sementes têm basicamente formato oval a triangular, com superfície normalmente verrucosa, planas (Fig. 6g) ou côncavo-convexas - convexas na face adaxial (Fig. 6h) e côncavas na face abaxial (Fig. 6i) - nas sementes côncavoconvexas há ainda na face abaxial uma estrutura chamada rafe (Fig. 6i) e representa a parte do funículo que permanece soldada à semente. É comumente proeminente e, às vezes, possui um par de excrescências laterais. As sementes podem ser aladas (Fig. 6g) ou não (Fig. 6h).

\section{Herbivoria}

Muitas espécies de Aristolochia frequentemente são atacadas por representantes em fase larval da tribo Troidini (Lepidoptera: Papilionidae), mais especificamente do gênero Battus Scopoli, 1777 e Parides Hübner, 1819 (Silva-Brandão \& Solferini 2007). A interação entre Troidini e Aristolochia tem sido utilizada como um exemplo clássico de co-evolução (Ehrlich \& Raven 1964; Brown et al. 1991). Troidini usam quase exclusivamente plantas de Aristolochia, e suas larvas são conhecidas por sequestrar os compostos secundários presentes em suas plantas hospedeiras (Klitzke 1992). 

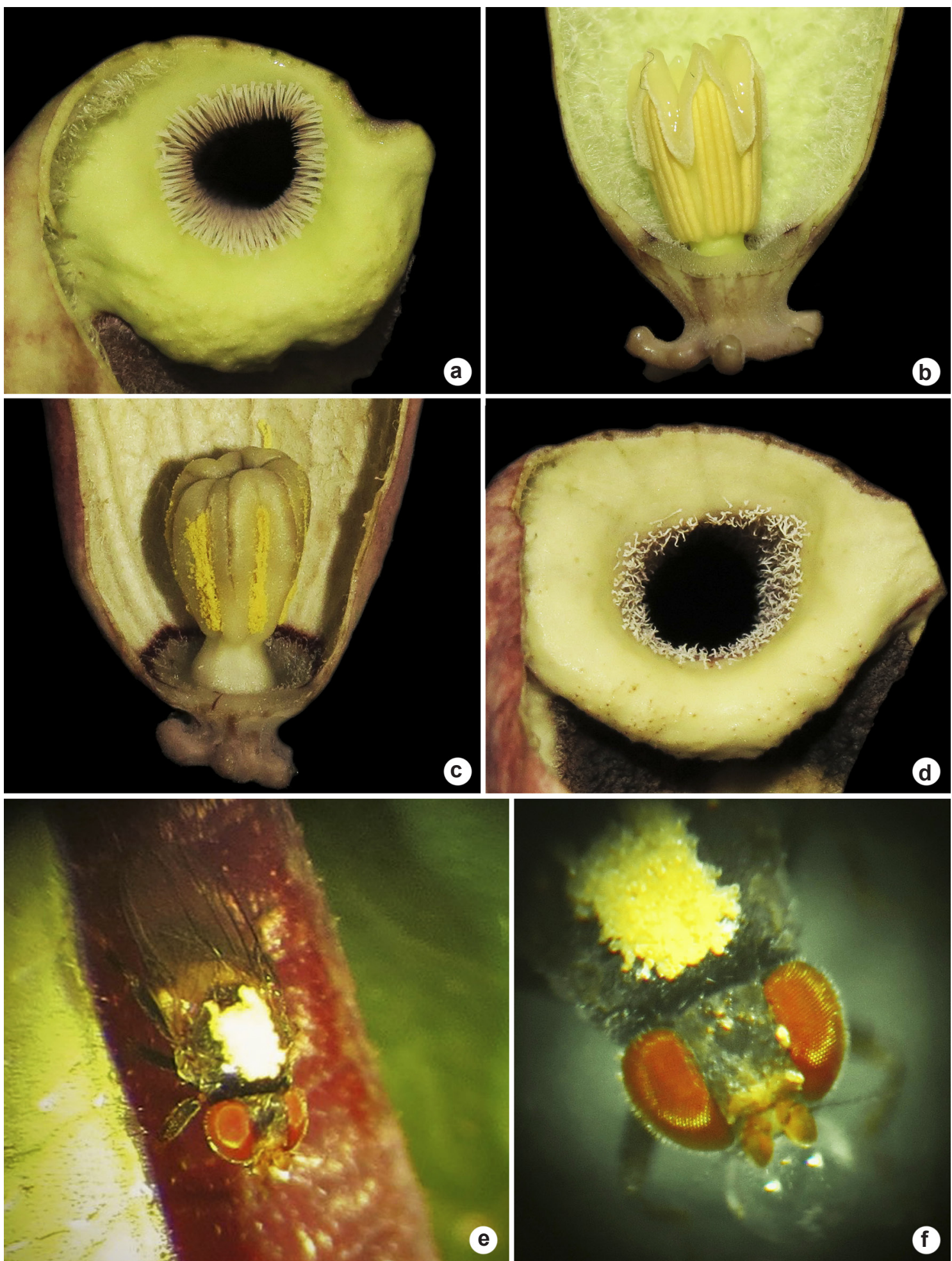

Figura 5 - a-d. protoginia - a. tricomas rígidos no interior do tubo; b. ginostêmio receptivo; c. lobos estigmáticos fechados e pólen liberado; d. tricomas frouxos após a liberação de pólen. e,f. polinizador em Aristolochia longispathulata - e. visão geral; f. dorso coberto por pólen.

Figure 5 - a-d. protogyny - a. rigid trichomes inside tube; b. receptive gynostemium; c. closed stigmatic lobes and pollen release; d. loose trichomes after pollen release. e,f. pollinator in Aristolochia longispathulata - e. overview; f. back covered by pollen. 
Para o Espírito Santo foi registrado pela primeira vez em literatura a herbivoria em Aristolochia, mais especificamente em $A$. hypoglauca (Freitas et al. em preparação) (Fig. 7). Indivíduos da lagarta também foram encontrados em A. pubescens, porém não foi observada a herbivoria.

\section{Tratamento taxonômico}

Vinte espécies de Aristolochia foram registrada no Espírito Santo. A ocorrência de Aristolochia gehrtii Hoehne, A. limai Hoehne, A. odora Steud.,
A. paulistana Hoehne e A. stomachoides Hoehne, anteriormente listadas com ocorrentes no ES (BFG 2015; Dutra et al. 2015), não foi confirmada. Essas espécies não foram coletadas durante a execução deste trabalho, e não foram encontrados materiais testemunhos das mesmas nas coleções visitadas, assim como nas bases de dados disponíveis online (SpeciesLink 2015; GBIF 2015).

O número de espécies encontradas corresponde a um acréscimo de $81 \%$ ao número anterior listado por Dutra et al. (2015) e BFG (2015) para o ES
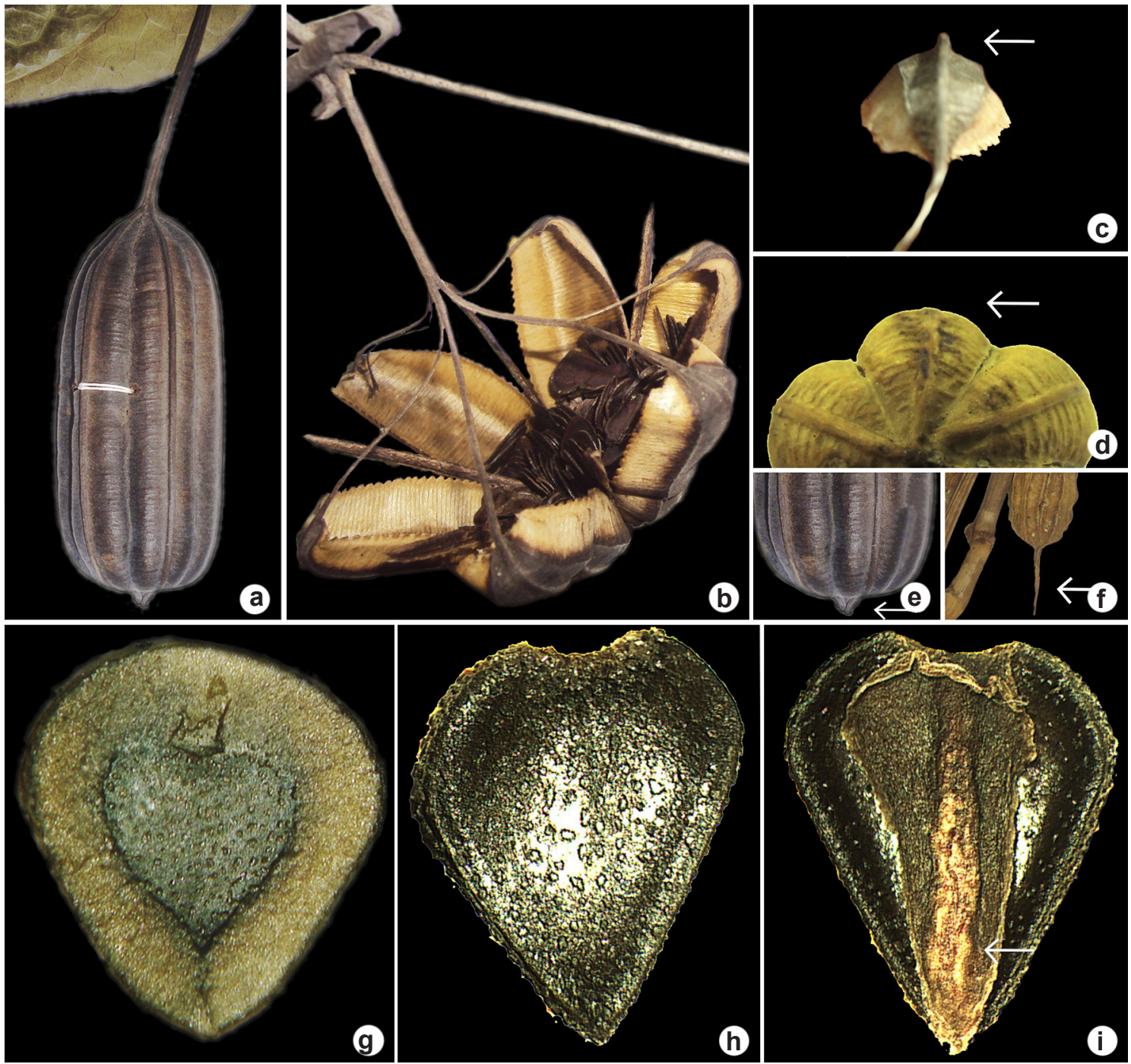

Figura 6 - a-f. fruto - a. fechado; b. aberto com sementes; c,d. mericarpo - c. veia média proeminente; d. veia média não proeminente; e,f. rostro - e. curto em A. hypoglauca; f. comprido em A. assisii. g-i. sementes - g. plana e alada; h. face adaxial verrucosa; i. face abaxial côncava com detalhe da rafe (seta).

Figure 6 - a-f. fruit - a. closed; b. open with seeds; c,d. mericarp - c. prominent midvein; d. non-prominent midvein; e,f. rostrum - e. short in A. hypoglauca; f. long in A. assisii. g-i. seeds - g. flat and winged; h. adaxial surface verrucose; i. abaxial surface concave with detailed raphe (arrow). 

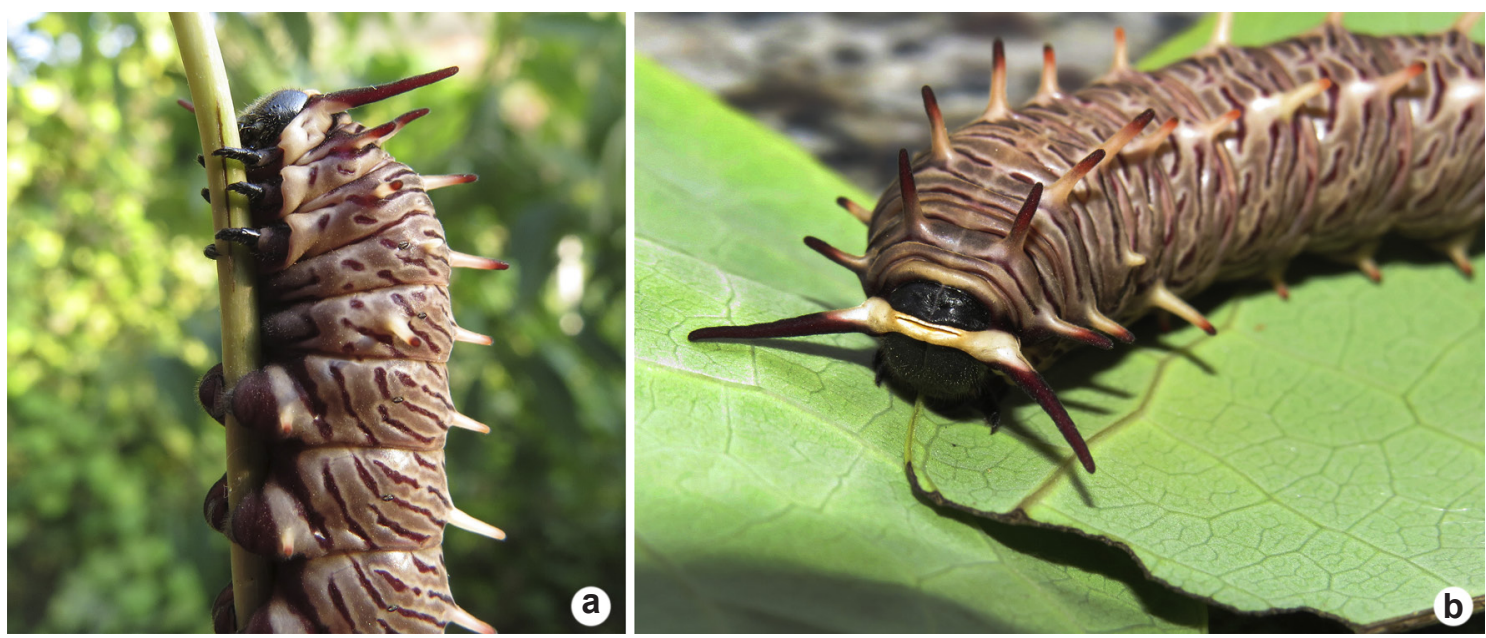

Figura 7 - Indivíduo da tribo Troidini (gênero Battus) predando Aristolochia hypoglauca no ramo (a) e folhas (b). Figure 7 - Troidini tribe individual (genus Battus) preying Aristolochia hypoglauca on branch (a) and leaves (b).

(11, já com o decréscimo das cinco espécies não confirmadas). Aristolochia cynanchifolia, A. elegans, A. gigantea, A. longispathulata, $A$. melastoma, $A$. nevesarmondiana e $A$. pubescens configuram-se novos registros para o estado.

Aristolochia pubescens foi categorizada como Vulnerável no estado do Espírito Santo, de acordo com os critérios da IUCN (2010, 2015), A. arcuata, A. bahiensis, A. cynanchifolia, A. hypoglauca, A. longispathulata, A. nevesarmondiana, A. tamnifolia e A. zebrina foram categorizadas como Em Perigo e Aristolochia assisii, A. chamissonis, A. melastoma e A. subglobosa como Criticamente Ameaçadas. A inclusão destes táxons na próxima atualização da Lista de Espécies Ameaçadas do Espírito Santo se faz necessária, uma vez que a atual lista (Kollmann et al. 2007) só aponta Aristolochia hypoglauca como extinta na natureza.

AFloresta Ombrófila Densa apresentou a maior riqueza de espécies (12 spp.), seguido da Floresta Estacional Semidecidual (oito spp.), Tabuleiro (seis spp.) e Restinga (quatro spp.). Embora a Floresta Ombrófila Densa tenha apresentado o maior número de espécies, as mesmas foram sempre encontradas em bordas de floresta, indicando a preferência das mesmas por esse tipo de ambiente.

\section{Chave de identificação de Aristolochiaceae no Espírito Santo, Brasil}

1. Pseudoestípulas presentes

2. Lâminas profundamente trilobadas 19. Aristolochia trilobata

2'. Lâminas inteiras

3. Limbo unilabiado

4. Limbo com base peltada

5. Lâminas amplamente ovais, base cordada; utrículo obovado a amplamente obovado

6. Pedúnculo + ovário $<10 \mathrm{~cm}$ compr.; limbo $<10 \mathrm{~cm}$ compr.

7. Aristolochia elegans

6'. Pedúnculo + ovário $>10 \mathrm{~cm}$ compr.; limbo $>10 \mathrm{~cm}$ compr.

7. Limbo 15,9-17,5 cm compr.; cápsulas $6,4-7,3 \mathrm{~cm}$ compr.; veia média de cada mericarpo proeminente $<1 \mathrm{~mm}$ espessura

9. Aristolochia aff. gigantea

7’. Limbo 28-29 cm compr.; cápsulas 10,7-13,3 cm compr.; veia média de cada mericarpo proeminente $3 \mathrm{~mm}$ espessura...8. Aristolochia gigantea

5'. Lâminas deltóides, base truncada a subcordada; utrículo orbicular a subgloboso.. 15. Aristolochia nevesarmondiana 
4'. Limbo com base não-peltada

8. Lâminas membranáceas; limbo oblongo a amplamente obovado, 1,8-2 cm compr., ápice arredondado a emarginado, fímbrias na margem ... 10. Aristolochia gracilipedunculata

8'. Lâminas papiráceas a cartáceas; limbo lanceolado, 20-35 cm compr., ápice agudo, fímbrias ausentes. 11. Aristolochia hypoglauca

3'. Limbo bilabiado

9. Lábio superior com base unguiculada 12. Aristolochia labiata

9'. Lábio superior com base cimbiforme. 5. Aristolochia cymbifera

1'. Pseudoestípulas ausentes

10. Inflorescências unifloras ou em racemos axilares com entrenós das flores $>5 \mathrm{~mm}$.

11. Flores com fímbrias no limbo

12. Lâmina estreito-oval a lanceolada, papirácea; perianto pubescente a pubérulo; limbo com base peltada

13. Limbo 3,3-3,7 cm compr., côncavo, ápice arredondado.... 1. Aristolochia arcuata

13'. Limbo 5,7-7 cm compr., convexo em quase todo o comprimento, ápice espatulado

13. Aristolochia longispathulata

12'. Lâmina amplamente oval, membranácea; perianto glabro; limbo com base não peltada 18. Aristolochia tamnifolia

11'. Flores sem fímbrias no limbo

14. Flores com perianto glabro ou glabrescente

15. Limbo com $1 / 5$ basal esbranquiçado com manchas roxo-escuras e tricomas pretos, o restante, amarelo esbranquiçado com listras roxo-escuras; margem inteira

20. Aristolochia zebrina

15'. Limbo com coloração uniforme vermelho; margem denteada.. ..6. Aristolochia cynanchifolia

14'. Flores com perianto hirsuto ou pubescente

16. Inflorescências unifloras, perianto hirsuto

16. Aristolochia pubescens

16'. Inflorescências em racemos, perianto pubescente.

14. Aristolochia melastoma

10'. Inflorescências em racemos caulifloros ou axilares com entrenós das flores $<1 \mathrm{~mm}$.

17. Ervas ca. $40 \mathrm{~cm}$ altura

2. Aristolochia assisii

17'. Trepadeiras

18. Limbo com ápice atenuado e caudado

4. Aristolochia chamissonis

18'. Limbo com ápice obtuso a arredondado e não caudado

19. Lâmina com base ligeiramente peltada; cápsula cilíndrica

3. Aristolochia bahiensis

19’. Lâmina com base não peltada; cápsula subglobosa

17. Aristolochia subglobosa

1. Aristolochia arcuata Mast., in Mart. Fl. bras., 4(2): 101. $1885 . \quad$ Figs. 8a,b; 10a,b

Trepadeiras. Caule suberoso. Ramos cilíndricos, entrenós 9,9-14,5 $\mathrm{cm}$ de compr. Pseudoestípulas ausentes. Pecíolo 2,8-5,2 cm de compr. glabro; lâmina estreito-oval a lanceolada, $15,1-18,1 \times 4,8-6,4 \mathrm{~cm}$, papirácea, face adaxial glabra e abaxial densamente pubescente, base profundamente cordada (sinus 2,8-3,5 cm de profundidade), não peltada, ápice agudo, venação primária basal 3(5). Inflorescências unifloras, não subtendidas por brácteas. Pedúnculo + ovário 4,5-
9,3 cm de compr. Perianto pubescente, verde claro com estrias verdes proeminentes; utrículo ovado, $1,6 \times 1,35-1,8 \mathrm{~cm}$; siringe ca. $1 \mathrm{~mm}$, equilátera; tubo funiforme, $2,3-2,6 \mathrm{~cm}$ compr. $\times 0,4-0,5$ cm (proximal) - 1,2-1,3 cm (distal) diâm; limbo unilabiado, estreito-oblongo, 3,3-3,7 × 1,1-1,2 $\mathrm{cm}$, côncavo, verde no $2 / 3$ proximal, coberto por tricomas esbranquiçados e verde com manchas pretas, glabro e com fímbrias pretas na borda no 1/3 distal, base obtusa, peltada, margem rugosa, ápice arredondado, acúmen ausente. Ginostêmio estipitado, ca. 5,5 mm compr., estipite 1-1,3 

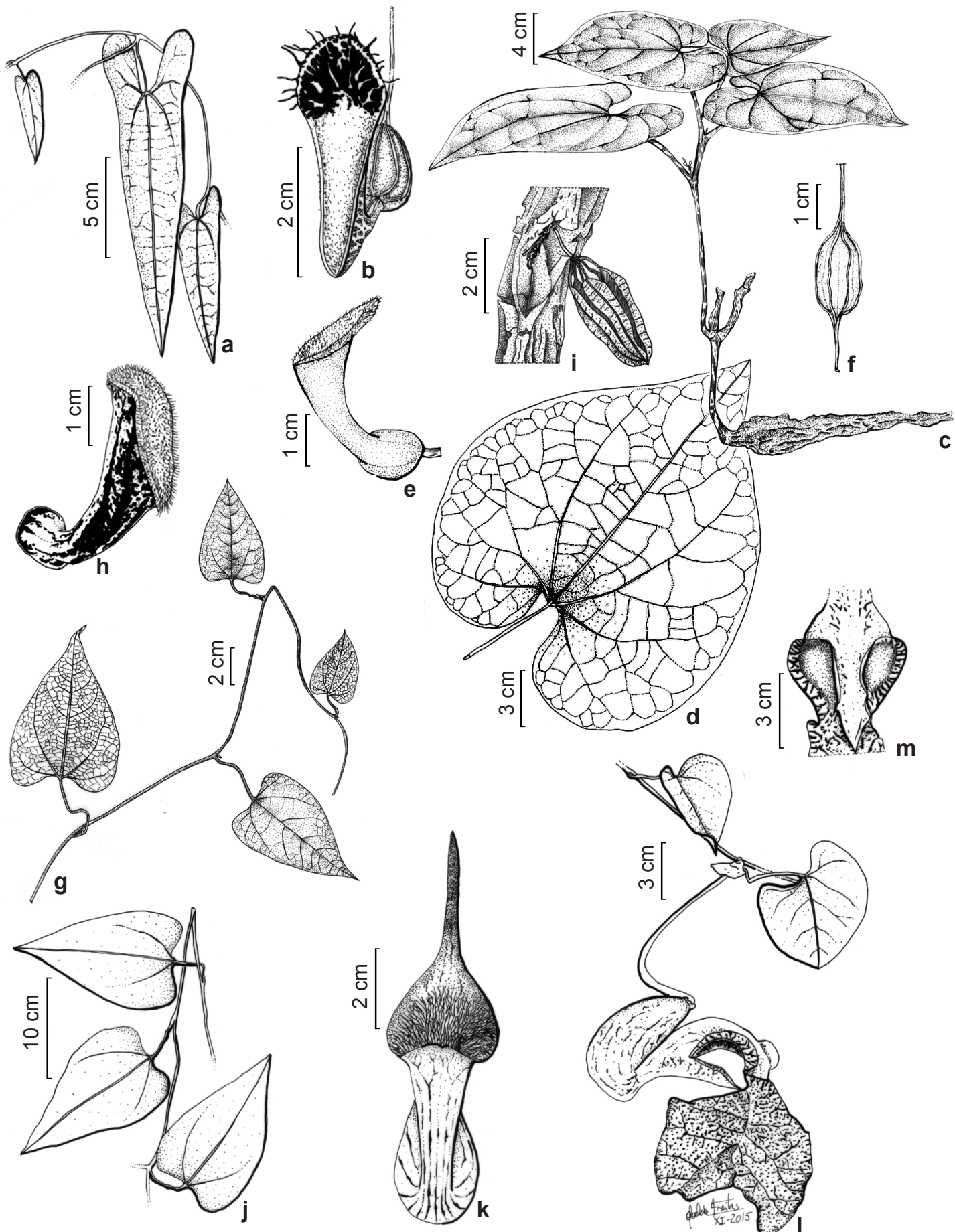

Figura 8 - a,b. Aristolochia arcuata - a. ramo; b. flor. c-f. Aristolochia assisii - c. hábito; d. folha; e. flor; f. fruto. g-i. Aristolochia bahiensis - g. ramo; h. flor. i. caule suberoso com infrutescência. j,k. Aristolochia chamissonis - j. ramo; k. flor. 1,m. Aristolochia cymbifera - 1. ramo florífero; m. detalhe da base cimbiforme da flor.

Figure 8 - a,b. Aristolochia arcuata - a. branch; b. flower. c-f. Aristolochia assisii - c. habit; d. leaf; e. flower; f. fruit. g-i. Aristolochia bahiensis - g. branch; h. flower; i. corky stems with infructescence. j,k. Aristolochia chamissonis - j. branch; k. flower. 1,m. Aristolochia cymbifera - 1. floriferous branch; $m$. detail of cymbiform base. 
mm compr.; anteras oblongas, 2,4 $\mathrm{mm}$ de compr. Cápsula estreito-cilíndrica, 4,8-8 × 1,9-2 cm, veia média do mericarpo proeminente, $<1 \mathrm{~mm}$ de espessura, rostrada, rostro ca. $3 \mathrm{~mm}$ de compr.; sementes ovais, $4,5 \times 3,5 \mathrm{~mm}$, côncavas, lisas, nãoaladas, rafe proeminente com duas excrescências laterais.

Material examinado: Vargem Alta, estrada para torre da Embratel, 4.II.2015, fl. e fr., J. Freitas et al. 350 (VIES). Material adicional examinado: BRASIL. SÃO PAULO: Nova Odessa, coletada por $H$. Lorenzi e floresceu em cultivo no sítio Primavera em Biritiba Ussu, Mogi das Cruzes, SP, 25.II.2015, fl e fr., J. Freitas 433 (MBML).

Possui distribuição para a Mata Atlântica e Cerrado, nos estados do Sudeste, CentroOeste e Paraná (BFG 2015). No ES, é registrada para Floresta Ombrófila Densa Montana, em bordas de floresta (Fig. 9). Dentre as espécies do ES, Aristolochia arcuata, representante de Aristolochia subsérie Hexandrae, é semelhante a A. longispathulata, porém difere desta pelo limbo côncavo de ápice arredondado e pelo seu comprimento de 3,3-3,7 cm (vs. convexo em quase todo o comprimento, ápice espatulado e comprimento de 5,7-7 cm). Aristolochia arcuata pode ser considerada Em Perigo (EN) no estado, de acordo com os critérios da IUCN $(2010,2015)$ : $\mathrm{A} 2 \mathrm{c}, \mathrm{B} 2 \mathrm{~b}$ (ii), $\mathrm{com} \mathrm{AOO}=20 \mathrm{~km}^{2}$.

2. Aristolochia assisii J. Freitas, Lírio \& F. Gonzalez, Phytotaxa 63(5): 263. 2014.

Figs. 8c-f; 10c-e

Ervas até $40 \mathrm{~cm}$ alt. Xilopódio subcilíndrico e tortuoso, suberoso, ramificado ou não, 38,2-63 cm compr., 1,7-2,9 cm diâm. Ramos cilíndricos, sulcado-estriados, entrenós ca. $9 \mathrm{~cm}$ compr. Pseudoestípulas ausentes. Pecíolo 5,6-16,5 cm compr., glabro, lâmina amplamente oval, 13,8-16,5 $\times 11,0-17,5 \mathrm{~cm}$, membranácea, face adaxial glabra, face abaxial pubérula, base profundamente cordada (sinus 2,8-4,4 $\mathrm{cm}$ de profundidade), não peltada, ápice acuminado, venação primária basal-7. Inflorescências em racemos axilares curtos, 4-30 mm compr., 6-23-floras, entrenós $<1 \mathrm{~mm}$

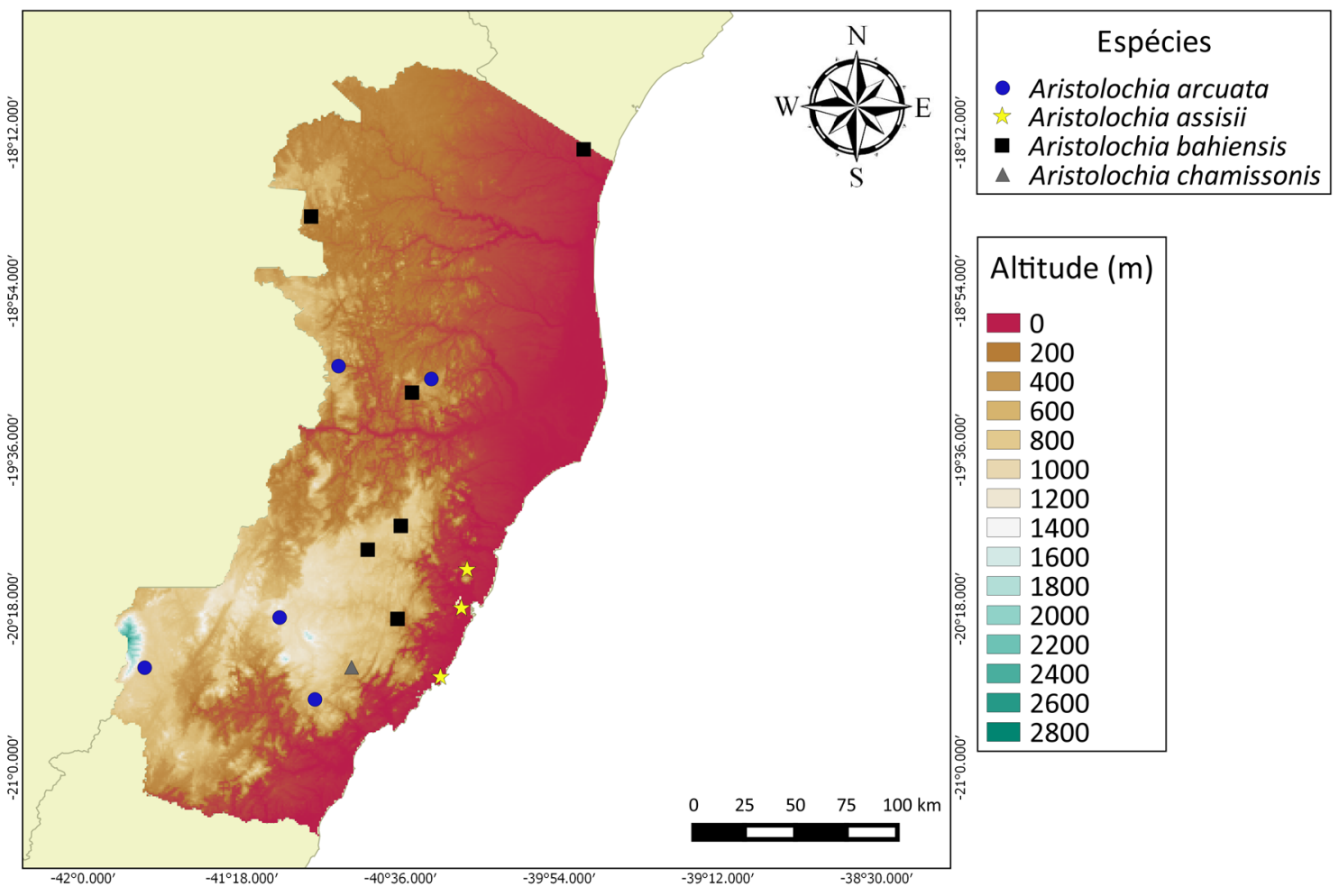

Figura 9 - Mapa de distribuição geográfica com camada altitudinal no estado do Espírito Santo - Aristolochia arcuata $(\bullet)$; Aristolochia assisii ( $\star$ ); Aristolochia bahiesis ( $\mathbf{\square})$; Aristolochia chamissonis $(\boldsymbol{\Delta})$.

Figure 9 - Map of geographic distribution with altitudinal layer in Espírito Santo state, Brazil - Aristolochia arcuata (•); Aristolochia assisii ( $\star$ ); Aristolochia bahiensis $(\boldsymbol{\square})$; Aristolochia chamissonis ( $\mathbf{\Delta})$. 
compr., subtendidos por brácteas estreito-ovais, $4,1 \times 2,9 \mathrm{~mm}$, curtamente pecioladas $<1 \mathrm{~mm}$, glabras. Pedúnculo + ovário 1,15-1,45 cm compr. Perianto glabro e de coloração bege externamente com estrias vináceas delgadas; utrículo ovóide, ca. 1,1 × 0,7 cm; siringe ca. 1,5 mm compr., inequilátera; tubo funiforme, ca. 1,66 cm compr. $\times 0,27 \mathrm{~cm}$ (proximal) - 0,77 cm (distal) diâm.;
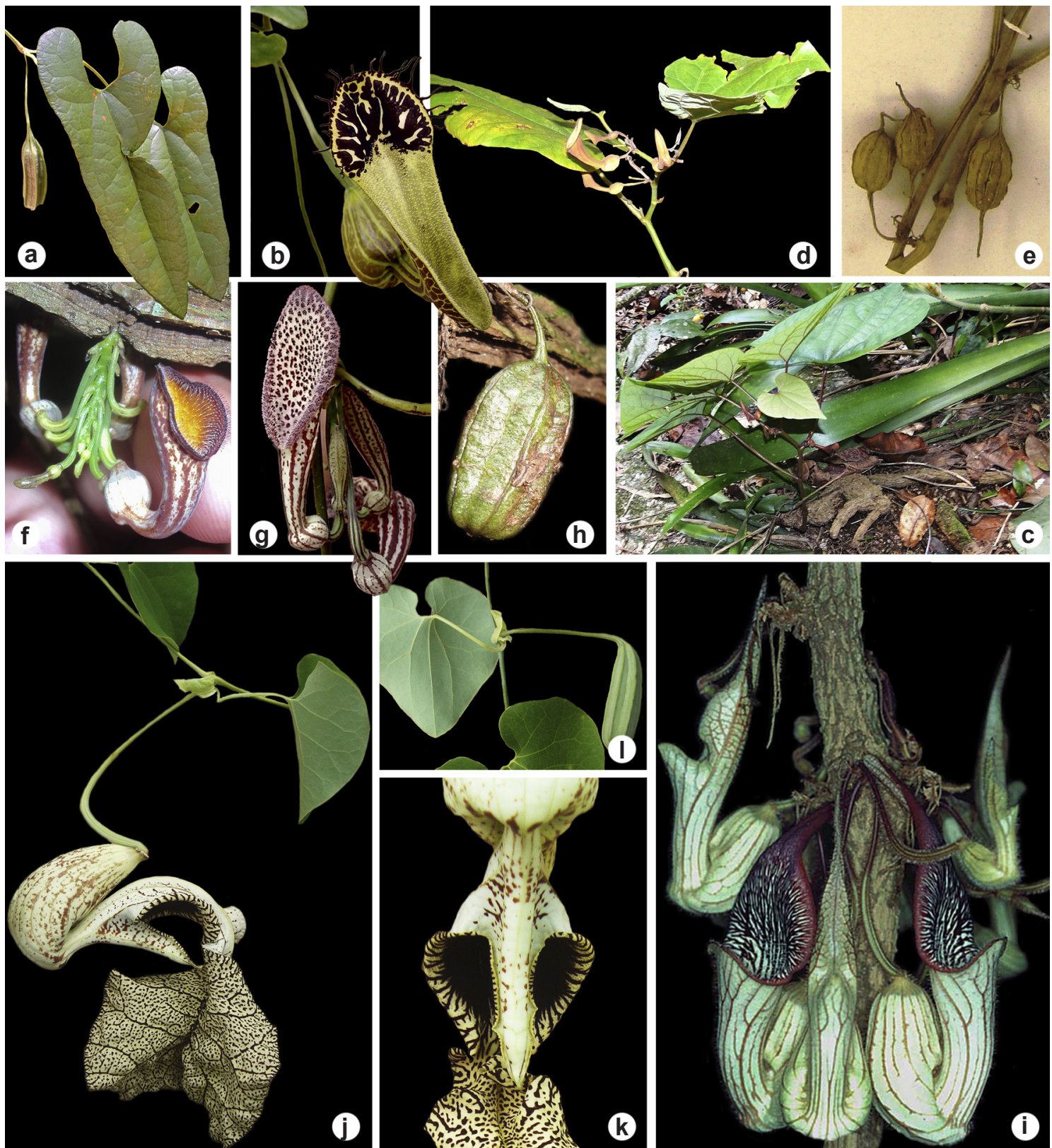

Figura 10 - a,b. Aristolochia arcuata - a. ramo; b. flor; c-e. Aristolochia assisii - c. hábito; d. detalhe da inflorescência; e. fruto. f-h. Aristolochia bahiensis - f. detalhe da inflorescência; g. flor pintagada de roxo; h. fruto. i. Aristolochia chamissonis - detalhe da inflorescência. j-1. Aristolochia cymbifera - j. fruto; k. detalhe da flor; 1 . detalhe da base cimbiforme. Fotos: a,b,e-g,h,j-1. Joelcio Freitas; c,d. André Moreira de Assis; i. Fernando Correa Campos Neto.

Figure 10 - a,b. Aristolochia arcuata - a. branch; b. flower. c-e. Aristolochia assisii - c. habit; d. detail of inflorescence; e. fruit. f-h. Aristolochia bahiensis - f. detail of inflorescence; g. flower with purple dots; h. fruit. i. Aristolochia chamissonis - detail of inflorescence. j-1. Aristolochia cymbifera - j. fruit; k. detail of flower; 1. detail of cymbiform base. Photos: a,b,e-g,h,j-1. Joelcio Freitas; c,d. André Moreira de Assis; i. Fernando Correa Campos Neto. 
limbo unilabiado, amplamente elíptico, 1,82-2 $\times 1,1-1,3 \mathrm{~cm}$, ligeiramente côncavo, vináceo no $1 / 6$ proximal e branco-amarelado com tricomas vináceos no $2 / 6$ distal, fímbrias ausentes, base emarginada, não peltada, margem revoluta, ápice obtuso, emarginado, acúmen ausente. Ginostêmio estipitado, 2,6-3 mm compr., estipite 1-1,2 $\mathrm{mm}$ compr.; anteras ca. 1,5 mm compr. Cápsula fusiforme, $3,2 \times 1,15 \mathrm{~cm}$, veia média do mericarpo proeminente, $<1 \mathrm{~mm}$ de espessura, rostrada, rostro ca. 1,2 cm compr. Sementes ovóides, ca. 4,1 × 3,3 $\mathrm{mm}$, côncavo-convexas, verrucosas, não-aladas, presença de rafe cilíndrica proeminente.

Material examinado: Guarapari, distrito de Setiba, mata seca de Restinga (Floresta não-inundável), 10.VII.1991, fr., L.V. da Rosa et al. 166 (VIES); 17.VIII.1991, fl., L.V. da Rosa et al. 204 (VIES). Serra, Mestre Álvaro - vertente sudeste, próximo a FURNAS, 20.IV.2013, fl., R. Santos 80 (MBML!); Acesso pelo Bairro Jardim Tropical, 23.III.2010, fl., A.M. Assis et al. 2327 (MBML); 7.VIII.2010, fl., A.M. Assis et al. 2597 (MBML). Vitória, Parque Estadual da Fonte Grande, 2004, fl. e fr., G.N. Martins 102 (VIES).

Possui distribuição restrita à Mata Atlântica, com ocorrência para os estados da Bahia e Espírito Santo (BFG 2015). No ES, é registrada para a Restinga e Floresta Ombrófila Submontana (sendo neste ambiente, encontrada sobre formações rochosas) (Fig. 9). Aristolochia assisii, representante de Aristolochia subsérie Anthocaulicae, é semelhante à A. bahiensis e A. subglobosa, porém difere destas pelo hábito herbáceo, único na subsérie Anthocaulicae (vs. trepadeiras lenhosas), florescimento relativamente rápido (vs. floração depois de muitos anos de crescimento vegetativo), fruto fusiforme ( $v s$. cilíndrico em $A$. bahiensis, e subgloboso em $A$. subglobosa), erostro de $1,2 \mathrm{~cm}$ de comprimento (vs. $1 \mathrm{~mm}$ compr.). Aristolochia assisii pode ser considerada Criticamente Ameaçada (CR) de acordo com os critérios da IUCN $(2010,2015)$ : $\mathrm{B} 1 \mathrm{~b}(\mathrm{i}), \operatorname{com} \mathrm{EOO}=46 \mathrm{~km}^{2}$.

\section{Aristolochia bahiensis F. González, Brittonia} 50: 8. 1998.

Figs. 8g-i; 10f-h

Trepadeiras. Caule suberoso. Ramos cilíndricos, entrenós 4,9-11,1 cm de compr. Pseudoestípulas ausentes. Pecíolo 1,3-5,1 cm de compr., a metade proximal um pouco mais espessada, glabro; lâmina estreitamente oval a oval-deltóide, $10-18,2 \times 4,3-8,2 \mathrm{~cm}$, papirácea a cartácea, face adaxial glabra, face abaxial pubérula, principalmente nas nervuras, base truncada ou cordada (sinus ca. 4-14 $\mathrm{mm}$ de profundidade), ligeiramente peltada, ápice agudo a acuminado, venação primária basal 3(5). Inflorescências em racemos caulifloros curtos, 4-13,4 $\mathrm{mm}$ de compr., 6-8 flores, entrenós $<1 \mathrm{~mm}$ compr., subtendidos por brácteas deltóides, 2-2,5 × 1,5-2 mm, pubérulas. Pedúnculo + ovário 1,3-3,8 cm de compr. Perianto glabro a pubescente, bege externamente com estrias vináceas espessadas; utrículo obovado, 3,7-8 × 3-5,5 mm; siringe $<1 \mathrm{~mm}$ compr., inequilátera; tubo funiforme, $0,9-2,3 \mathrm{~cm}$ de compr. $\times 0,2-0,37$ $\mathrm{cm}$ (proximal) - 0,45-0,71 cm (distal) diâm.; limbo unilabiado, amplamente oval a elíptico, 1,1-2,1 $\times$ 0,6-1,4 cm, côncavo, vináceo a amarelo com tricomas esbranquiçados ou branco com pintas roxas e tricomas esbranquiçados, fímbrias ausentes, base obtusa, não peltada, margem revoluta, ápice obtuso, terminando num curto acúmen, $<1 \mathrm{~mm}$. Ginostêmio estipitado, 1,7-4 mm compr., estipite 1-1,5 mm compr.; anteras $0,9-1,5 \mathrm{~mm}$ de comp. Cápsula cilíndrica, $1,8-3,8 \times 0,9-1,7 \mathrm{~cm}$, veia média do mericarpo não proeminente ou com $<1$ $\mathrm{mm}$, curtamente rostrada, rostro $<1 \mathrm{~mm}$ compr. Sementes ovóides, 4,2-5,6×3,6-4,6 mm, côncavoconvexas, verrucosas, não-aladas, presença de rafe cilíndrica proeminente.

Material examinado: Marilândia, Alto Liberdade, Pedra do Cruzeiro, 5.VIII.2014, fr., J. Freitas et al. 252 (MBML; VIES); J. Freitas et al. 253 (MBML; VIES). Pedro Canário, Reserva Biológica Córrego Grande, Km 4, 11.XI.2014; fl. e fr., J. Freitas 286 (MBML); Cultivada no Instituto Nacional da Mata Atlântica, floresceu em cultivo em 16.III.2015, fl., J. Freitas 283 (MBML). Santa Maria de Jetibá, São José do Rio Claro, propr. Alfredo Renok, interior da capoeira, próxima à caixa d'água grande, 21.IV.2009, fl., J. Freitas 06 (MBML); 1.VI.2012, fr., J. Freitas \& L. Tonini 160 (MBML); Santa Teresa, Valsugana Velha, Estação Biológica de Santa Lúcia, 8.II.2011, fl., L. Kollmann et al. 12176 (MBML). Município desconhecido, propr. Sr. Alberto Lutzke III, local conhecido por Galo. XII.1983, fl., R.A. Kautski 832 (RB).

Possui distribuição restrita à Mata Atlântica, para os estados da Bahia e Espírito Santo (BFG 2015). No ES, é registrada para a Floresta Ombrófila Densa Montana (Fig. 9) e geralmente próximo à borda de floresta. Aristolochia bahiensis pertence à $A$. subsérie Anthocaulicae e é morfologicamente semelhante a $A$. assisii A. subglobosa porém difere de ambas pela base levemente peltada da folha ( $v s$. não peltada) e pelo fruto cilíndrico ( $v s$. subgloboso em A. subglobosa e fusiforme em A. assisii). Embora tenha sido encontrado um espécime com flores de limbo branco com pintas roxas (o comumé coloração amarela), também foi determinado como 
esta espécie, por não apresentar outros caracteres para sua separação a nível específico. Aristolochia bahiensis pode ser considerada Em Perigo (EN) de acordo com os critérios da IUCN (2010, 2015): $\mathrm{A} 2 \mathrm{c}, \mathrm{B} 2 \mathrm{~b}(\mathrm{ii}), \operatorname{com} \mathrm{AOO}=24 \mathrm{~km}^{2}$.

4. Aristolochia chamissonis (Klotzsch) Duch., Prodr.15 (1): 462.1864.

Figs. 8j,k; 10i

=Howardia chamissonis Klotzch, Monatsber. Königl. Preuss. Akad. Wiss. Berlin: 615-616. 1859.

Trepadeiras. Caule suberoso. Ramos cilíndricos, entrenós 12,5-17 cm de compr. Pseudoestípulas ausentes. Pecíolo 4,7-5,5 cm de compr., piloso; lâmina oval-deltóide, 15,7-23 × 9,6-13,4 cm, cartácea, face adaxial glabra, face abaxial pubérula, base truncada, subcordada a profundamente cordada (sinus 1-3,2 cm de profundidade), não peltada, ápice agudo a acuminado, venação primária basal 3(5). Inflorescências em racemos caulifloros curtos, ca. $15 \mathrm{~mm}$ de compr., 5-6 flores, entrenós $<1 \mathrm{~mm}$ compr. Pedúnculo + ovário $5-8,5 \mathrm{~cm}$ de compr. Perianto piloso, bege externamente com estrias vináceas; utrículo oval, 2,8-4,4 × 1,8-2,8 cm; siringe não vista; tubo funiforme, $2,2-5 \mathrm{~cm}$ de compr. $\times 0,5-1,9 \mathrm{~cm}$ (proximal) - 1,4-2,3 cm (distal) diâm.; limbo unilabiado, oval-lanceolado, $5,7 \times 1,7 \mathrm{~cm}$, côncavo, bege com estrias vinaceas, glabro, fímbrias ausentes, base emarginada, não peltada, margem revoluta, ápice atenuado e caudado, acúmen ausente. Ginostêmio não estipitado, 9-10 mm compr.; anteras oblongas. Cápsula estreito-cilíndrica, 7,3 ×2,1 cm, veia média do mericarpo proeminente, $<1 \mathrm{~mm}$ de espessura, não rostrada. Sementes amplamente ovais, $6 \times 5$ $\mathrm{mm}$, planas, verrucosas, não-aladas, rafe ausente. Material examinado: Entre Iconha e Cachoeiro de Itapemirim, 28.XI.1953, fl., A.P. Duarte 3639 (RB).

Material adicional examinado: BRASIL. MINAS GERAIS: Descoberto, Reserva Biológica da Represa do Grama, 9.XII.2001, fl., R.M. Castro 752 (RB). PARANÁ: Guaraqueçaba, Salto Murato, 15.XI.1992, fr., G. Hatschbach 59774 (HUEFS).

Possui distribuição na Mata Atlântica e Cerrado, para todo o Sudeste e os estados de Goiás e Paraná (BFG 2015). No ES, A. chamissonis é considerada rara e, anteriormente ao atual trabalho, havia uma única coleta registrada em herbário feita há mais de 60 anos. Recentemente, uma população da espécie foi encontrada no município de Alfredo Chaves (Fig. 9), em Floresta Ombrófila Densa Montana, com amostras em cultivo no INMA. Aristolochia chamissonis, representante de $A$. subsérie Anthocaulicae, difere das demais espécies pela flor com o ápice do limbo acuminado e caudado (característica ausente nas demais). As características de hábitat também são relevantes, uma vez que $A$. chamissonis ocorre preferencialmente próxima a cursos d'água (Hoehne 1927), as demais espécies desta subsérie sempre ocorrem em bordas de mata, em ambientes xéricos ou raramente em interior de floresta. Aristolochia chamissonis pode ser considerada Criticamente Ameaçada (CR) de acordo com os critérios da IUCN (2010, 2015): A2c, B2ab(ii,iii), $\operatorname{com} \mathrm{AOO}=4 \mathrm{~km}^{2}$.

5. Aristolochia cymbifera Mart., Nova Genera et Species Plantarum, 1: 76. 1823. Figs. 81,m; 10j-1

Trepadeiras. Caule suberoso. Ramos cilíndricos, entrenós 8,5-13,5 cm de compr. Pseudoestípulas presentes, amplamente ovadas, $2,5 \times 2 \mathrm{~cm}$. Pecíolo 5-7 cm de compr., piloso; lâmina amplamente oval, 7,2-16 × 7,3-15,2 $\mathrm{cm}$, papirácea, face adaxial glabra e abaxial glabrescente, base profundamente cordada (sinus 1,6-4,6 cm de profundidade), não peltada, ápice arredondado a acuminado, venação primária basal 3(5). Inflorescências unifloras, não subtendidas por brácteas. Pedúnculo + ovário 14,5-15 cm de compr. Perianto glabro, bege a branco com estrias vináceas a enegrecidas; utrículo obovado, 6,1-7,1 $\times 3-3,4 \mathrm{~cm}$; siringe ca. 4,5 mm, inequilátera; tubo funiforme, $4 \mathrm{~cm}$ compr. $\times 0,9 \mathrm{~cm}$ (proximal) - 2,9 cm (distal) diâm; limbo bilabiado, côncavo, bege com estrias amarronzadas a enegrecidas, fímbrias ausentes, base peltada; lábio superior obovado, 14-18 × 9,6-12 cm, base cimbiforme, margem revoluta, ápice obcordado, acúmen ausente; lábio inferior carenado, 3,1-5,1 × 1,7-4 cm, margem revoluta, ápice mucronulado. Ginostêmio nãoestipitado, $7 \mathrm{~mm}$ compr.; anteras oblongas, $5 \mathrm{~mm}$ de compr. Cápsula estreito-cilíndrica, 7,4-9,9 × $3,2-3,9 \mathrm{~cm}$, veia média do mericarpo proeminente, $<1,5 \mathrm{~mm}$ de espessura, rostrada, rostro ca. $2 \mathrm{~mm}$ de compr. Sementes ovais, $9 \times 7 \mathrm{~mm}$, planas, lisas, não-aladas, rafe ausente.

Material examinado: Atílio Vivacqua, Moitão, 27.IV.2007, fl. e fr., L. Kollmann et al. 9762 (MBML). Cariacica, arredores da REBIO Duas Bocas, próximo à sede, fl., R.C. Forzza et al. 5403 (MBML, RB); beira de estrada para a localidade de Alegre, fl. e fr., C.N. Fraga et al. 2476 (MBML, RB). Fundão, estrada Fundão-Nova Almeida, 28.I.2007, fl., L. Kollmann \& R.L. Kollmann 9484 (MBML); beira da BR-101, sentido Ibiraçú, 22.IX.2014, fl. e fr., J. Freitas 258 (MBML; VIES). 
Aristolochia cymbifera, representante de $A$. subsérie Hexandrae, possui distribuição restrita à Mata Atlântica, para todo o Sudeste (BFG 2015). No ES, é registrada para diversas formações (Fig. 12), sendo frequentemente associada às bordas de floresta ou mais comumente em beira de estradas. A espécie é semelhante a $A$. labiata, porém difere desta pela base do limbo superior cimbiforme (unguiculado em A. labiata). Aristolochia cymbifera pode ser considerada Menos preocupante (LC) de acordo com os critérios da IUCN (2015), devido à sua ampla distribuição no estado do ES.

6. Aristolochia cynanchifolia Mart., Nov. Gen. Sp. P1., 1: 77. 1824.

Figs. 11a,b; 13a,b

Trepadeiras. Caule suberoso. Ramos cilíndricos, entrenós 4,7-7,9 cm de compr. Pseudoestípulas ausentes. Pecíolo 1,5-2,8 cm de compr. glabro; lâmina estreito-oval, 6,5-14 $\times 2,3-5,2 \mathrm{~cm}$, papirácea a cartácea, face adaxial e abaxial glabras, base cordada (sinus ca. 4,5 $\mathrm{mm}$ de profundidade), não peltada, ápice agudo a levemente acuminado, venação primária basal 3(5). Inflorescências unifloras, não subtendidas por brácteas. Pedúnculo + ovário 7,2-8 $\mathrm{cm}$ de compr. Perianto glabro, bege com estrias vináceas; utrículo suborbiculado, $2,4 \times 1,8 \mathrm{~cm}$; siringe ausente; tubo funiforme, $1,1 \mathrm{~cm}$ compr. $\times 0,4 \mathrm{~cm}$ (proximal) - 0,7 cm (distal) diâm; limbo unilabiado, estreitooblongo, 4,9 $\times 0,5 \mathrm{~cm}$, convexo, vermelho, glabro, fímbrias ausentes, base unguiculada, não-peltada, margem denteada, ápice agudo, acúmen ausente. Ginostêmio estipitado, ca. $5 \mathrm{~mm}$ compr., estipite $1 \mathrm{~mm}$ compr.; anteras oblongas, $3 \mathrm{~mm}$ de compr. Cápsula curtamente cilíndrica, 2-3,6 × 1,5-2 $\mathrm{cm}$, veia média do mericarpo não proeminente, rostrada, rostro 2-2,5 $\mathrm{mm}$ de compr.; sementes amplamente ovais, $5 \times 4,5 \mathrm{~mm}$, planas, verrucosas, não-aladas, rafe proeminente.

Material examinado: Itapemirim, Fazenda do Ouvidor - Usina Paineiras, porção oeste do Fragmento de 600 ha. 15.III.2008, fr., A.M. Assis et al. 1461 (MBML). Santa Leopoldina, Suíça, 12.IV.2008, fr., M. Simonelli et al. 1497 (MBML). Santa Maria de Jetibá, Rio Bonito, entorno da PCH de Rio Bonito, 2.VII.2015, fr., J. Freitas et al. 415 (MBML; VIES); 25.XII.2015, fl. e fr., E.J. Lírio 1440 (MBML). Santa Teresa, Santo Antônio, terreno do Boza, 15.VI.1999, fl., L. Kollmann et al. 2559 (MBML). Vargem Alta, reserva particular do Patrimônio Natural Mata da Serra, 6.II.2015, fr., J. Freitas et al. 360 (MBML).

Possui distribuição restrita à Mata Atlântica, endêmica até então para o estado do Rio de Janeiro (BFG 2015), sendo este o primeiro para o Espírito
Santo. Encontrada em Florestas Ombrófila Densa Montana e Submontana (Fig. 12), a espécie ocorre em ambientes com maior intensidade luminosa ou no interior de floresta. Dentre as espécies capixabas sem pseudoestípulas, $A$. cynanchifolia é uma representante de $A$. subsérie Hexandrae e morfologicamente próxima à $A$. arcuata e $A$. longispathulata, diferindo destas pelo limbo com margem denteada (vs. margem rugosa), ausência de fímbrias (vs. presentes nas demais) e pela face abaxial da folha glabra (vs. densamente pubescente). Aristolochia cynanchifolia pode ser considerada Em Perigo (EN) de acordo com os critérios da IUCN $(2010,2015)$ : A2c, B1(ii,iii) + 2ab(ii,iii), $\operatorname{com} \mathrm{AOO}=20 \mathrm{~km}^{2}$ e EOO $=674 \mathrm{~km}^{2}$.

7. Aristolochia elegans Mast., Gard. Chron., 24(610): 301. $1885 . \quad$ Figs. 11c; 13c

Trepadeiras. Caule suberoso. Ramos cilíndricos, entrenós 5,6-13 cm de compr. Pseudoestípulas presentes, suborbiculares, $2 \times$ 1,9 cm. Pecíolo 2,6-3,8 cm de compr. glabro; lâmina amplamente oval, $6,3-6,6 \times 7-7,8 \mathrm{~cm}$, papirácea, face adaxial e abaxial glabras, base cordada (sinus 1,3-1,4 cm de profundidade), não peltada, ápice arredondado, venação primária basal 5(7). Inflorescências unifloras não subtendidas por brácteas. Pedúnculo + ovário 5,4-7,9 cm de compr. Perianto glabro, bege com manchas vináceas; utrículo amplamente obovado, 2,9 × 1,4 $\mathrm{cm}$; siringe ca. $1 \mathrm{~mm}$, inequilátera; tubo funiforme, $2,2 \mathrm{~cm}$ compr. $\times 0,6 \mathrm{~cm}$ (proximal) $-1,1 \mathrm{~cm}($ distal $)$ diâm; limbo unilabiado, oval, 7,8 × 7,6 cm, plano, amarelado próximo à entrada do tubo e bege com manchas vináceas no restante, fímbrias ausentes, base cordada, peltada, margem levemente revoluta, ápice arredondado, terminando num curto acúmen, $<1 \mathrm{~mm}$. Ginostêmio não estipitado, $6,9 \mathrm{~mm}$ compr.; anteras lineares, $4 \mathrm{~mm}$ de compr. Cápsula estreito-cilíndrica, $4,4 \times 1,6 \mathrm{~cm}$, veia média do mericarpo proeminente, $<1 \mathrm{~mm}$ de espessura, rostrada, rostro $0,9 \mathrm{~mm}$ de compr.; sementes não vistas.

Material examinado: Santa Teresa, centro da cidade, ponte ao lado do restaurante Cantina Italiana, 2.X.2015, fl., J. Freitas 432 (MBML).

Material adicional examinado: BRASIL. MINAS GERAIS: São Roque de Minas, Serra da Canastra, ao lado da Igreja do Vilarejo dos Leite, 17.I.2007, fr., A.A. Didonet 05 (RB; MBML).

Possui distribuição para diversos estados da Mata Atlântica, Amazônia e Cerrado (BFG 2015). Aristolochia elegans é registrada pela primeira vez para o ES, embora a coleta tenha sido feita em 
cultivo, a proximidade desta a um rio, pode facilitar sua dispersão (Fig. 12). Aristolochia elegans, pertence à $A$. subsérie Hexandrae e é semelhante a A. gigantea e Aristolochia aff. gigantea, porém difere delas pelo comprimento do limbo $(7,8$ cm) vs. 28-29 cm em A. gigantea e 15,9-17,5 $\mathrm{cm}$ em Aristolochia aff. gigantea. Aristolochia elegans não foi avaliada quanto ao seu status de conservação, devido ao seu registro ser apenas em cultivo para o estado.

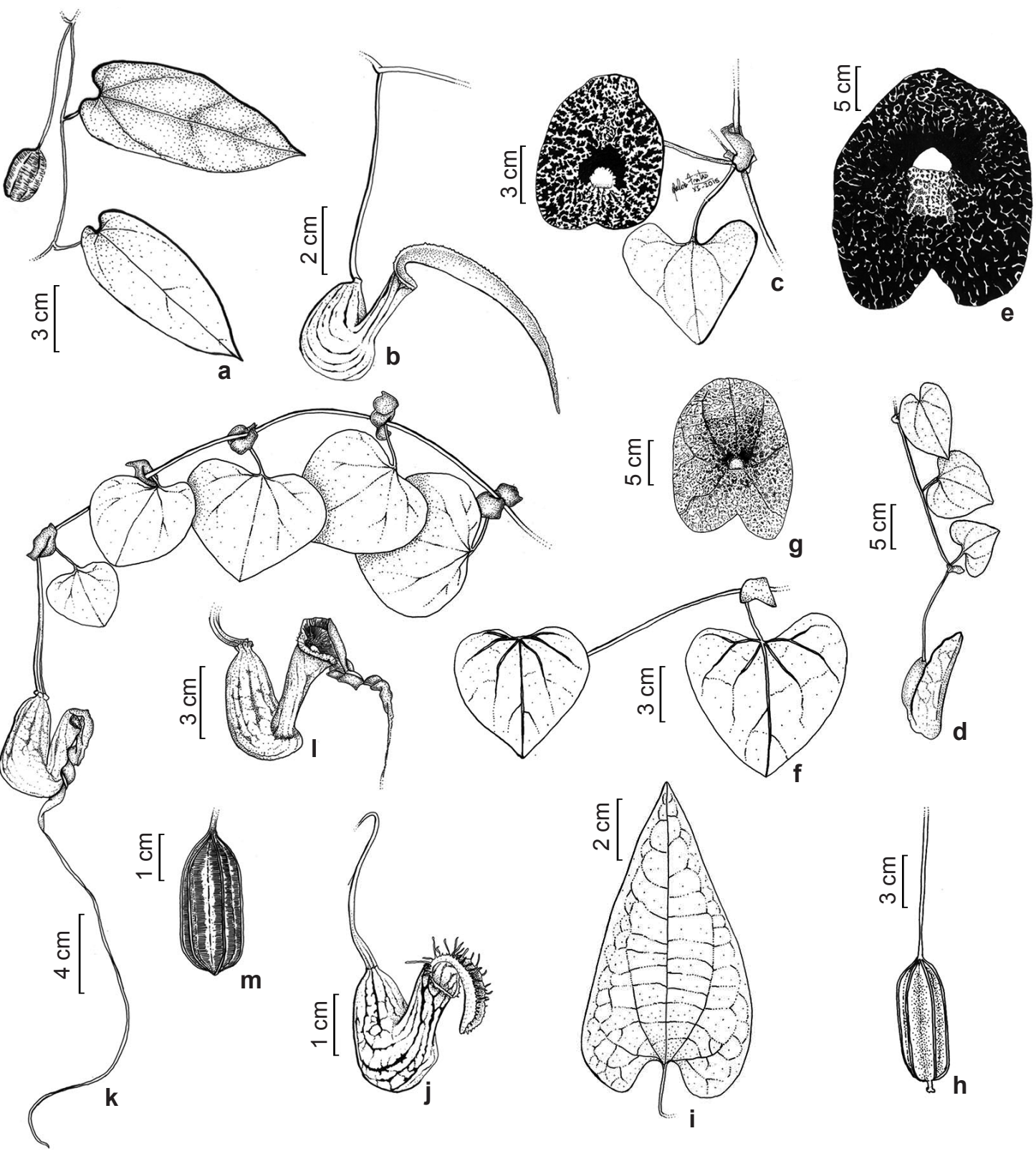

Figura 11 - a,b. Aristolochia cynanchifolia - a. ramo frutífero; b. flor. c. Aristolochia elegans - ramo florífero. d,e. Aristolochia gigantea - d. ramo florífero; e. flor. f-h. Aristolochia aff. gigantea - f. ramo; g. flor; h. fruto. i,j. Aristolochia gracilipedunculata - i. folha; j. flor. k-m. Aristolochia hypoglauca - k. ramo florífero; 1. flor; m. fruto. Figure 11 - a,b. Aristolochia cynanchifolia - a. fructiferous branch; b. flower. c. Aristolochia elegans - floriferous branch. d,e. Aristolochia gigantea - d. floriferous branch; e. flower. f-h. Aristolochia aff. gigantea - f. branch; g. flower; h. fruit. i,j. Aristolochia gracilipedunculata - i. leaf; j. flower. k-m. Aristolochia hypoglauca - k. floriferous branch; 1. flower; m. fruit. 
8. Aristolochia gigantea Mart. \& Zucc., Nov. Gen. Sp. Pl. 1: 77. 1824.

Figs. 11d,e; 13d,e

Trepadeiras. Caule suberoso. Ramos sulcado-estriados, entrenós 8,5-14,5 cm compr. Pseudoestípulas presentes, estreito-ovais, 1,8-2,2 $\times 0,8-2,2 \mathrm{~cm}$. Pecíolo 5,4-7,1 cm compr. glabro; lâmina amplamente oval, 8,2-11,3 × 7,5-10 cm, papirácea, face adaxial e abaxial glabras, base cordada (sinus $1-1,6 \mathrm{~cm}$ de profundidade), não peltada, ápice agudo a levemente acuminado, venação primária basal 5(7). Inflorescências unifloras não subtendidas por brácteas. Pedúnculo + ovário 21,5-28,5 cm de compr. Perianto glabro, bege com manchas vináceas; utrículo amplamente obovado, 7,3-8,3 × 4,7-5 cm, glauco, base estreita abrigando o gimnostêmio; siringe ca. $3 \mathrm{~mm}$, inequilátera; tubo funiforme, $3,2-3,5 \mathrm{~cm}$ compr. $\times$ $0,7-0,5 \mathrm{~cm}$ (proximal) $-1,1-1,9 \mathrm{~cm}$ (distal) diâm; limbo unilabiado, oval, $28-29 \times 22-24 \mathrm{~cm}$, plano, amarelado próximo à entrada do tubo e bege com manchas vináceas no restante, fímbrias ausentes, base cordada, peltada, margem levemente revoluta, ápice arredondado, terminando num curto acúmen,
$<1 \mathrm{~mm}$. Ginostêmio estipitado, $13 \mathrm{~mm}$ compr., estípite 1-1,5 mm compr.; anteras lineares, $8 \mathrm{~mm}$ de compr. Cápsula estreito-cilíndrica, 10,7-13,3 × 2,4-2,6 cm, veia média do mericarpo proeminente, $3 \mathrm{~mm}$ de espessura, rostrada, rostro $0,8-0,9 \mathrm{~mm}$ de compr.; sementes amplamente ovais, 9-10 $\times$ 6-7 mm, planas, verrucosas, não-aladas, rafe não proeminente.

Material examinado: Santa Maria de Jetibá, Rio Bonito, entorno da PCH de Rio Bonito, 2.VII.2015, fl e fr., $J$. Freitas et al. 416 (MBML; VIES); 10.V.2000, fr., E.J. Lírio 553 (MBML).

Material adicional examinado: BRASIL. BAHIA: Coribe, a 24,4 km de São Felix do Coribe, 10.IV.2007, fl, L.P. Queiroz et al. 12743 (HUEFS). Lafaiete Coutinho, na beira da estrada, 19.V.2002, fr., L.C. Senra et al. 26 (HUEFS).

Possui distribuição restrita à Mata Atlântica para os estados da Bahia, Minas Gerais, Rio de Janeiro, São Paulo e Paraná (BFG 2015). No ES, apenas um registro em Floresta Ombrófila Densa Montana foi feito (Fig. 12), porém a área é próxima à um antigo empreendimento, o que colocou em dúvida se também é uma espécie

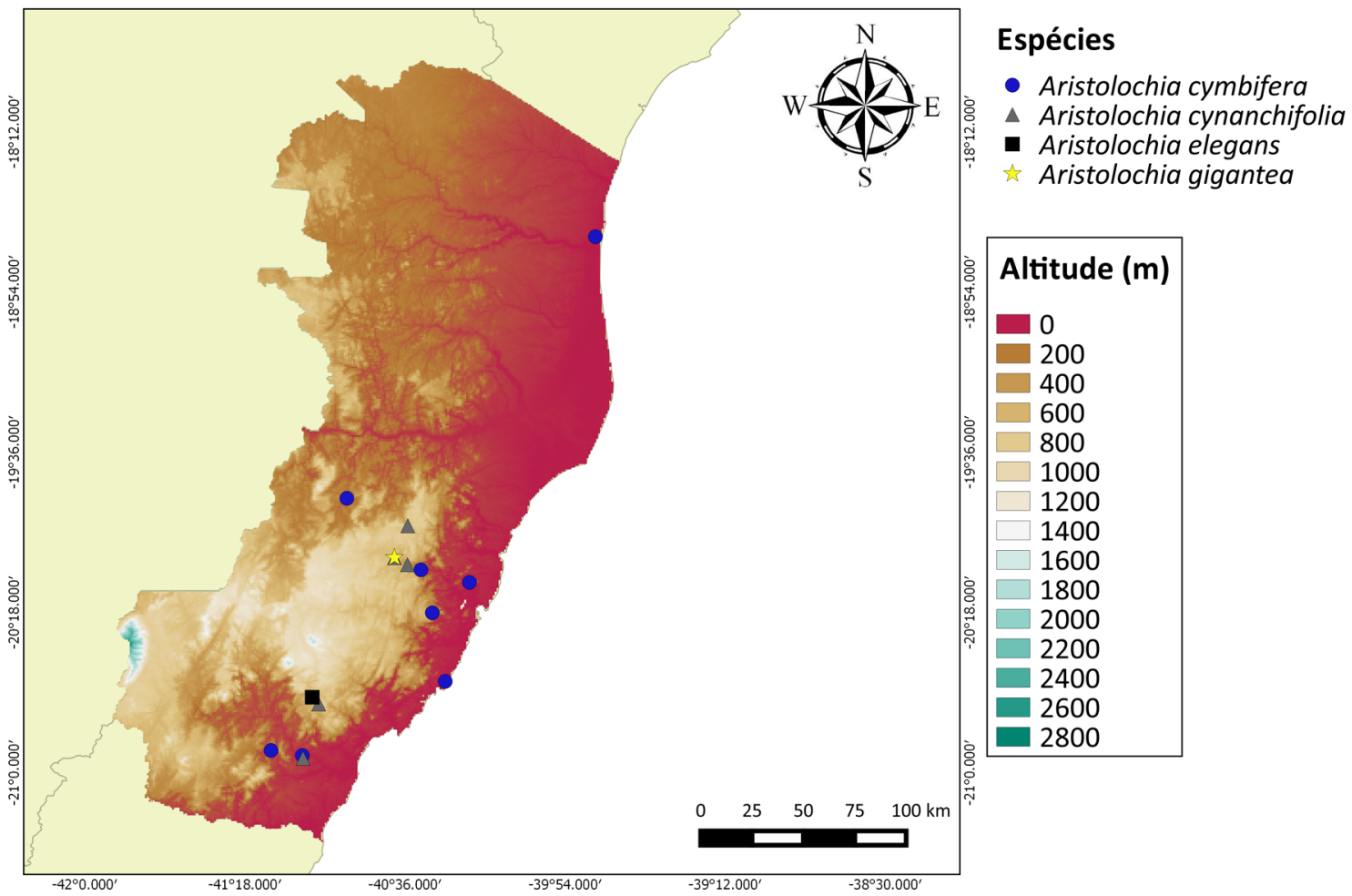

Figura 12 - Mapa de distribuição geográfica com camada altitudinal no estado do Espírito Santo - Aristolochia cymbifera $(\bullet)$; Aristolochia cynanchifolia $(\mathbf{\Delta})$; Aristolochia elegans $(\mathbf{\square})$; Aristolochia gigantea $(\star)$. Figure 12 - Map of geographic distribution with altitudinal layer in Espírito Santo state, Brazil - Aristolochia cymbifera (•); Aristolochia cynanchifolia ( $\mathbf{\Delta})$; Aristolochia elegans $(\mathbf{\square})$; Aristolochia gigantea $(\star)$. 
cultivada. Aristolochia gigantea, representante de $A$. subsérie Hexandrae, é morfologicamente semelhante a $A$. elegans e Aristolochia aff. gigantea (a discussão referente a morfologia de A. gigantea e de suas espécies relacionadas estão nos comentários de A. elegans). Aristolochia gigantea não foi enquadrada em nenhum critério de ameaça, devido ter sido encontrada numa área com interferência antrópica, o que pode indicar a sua introdução naquele ambiente.
9. Aristolochia aff. gigantea Mart. \& Zucc., Nov. Gen. Sp. Pl. 1: 77. 1824. Figs. 11f-h; 13f-h

Trepadeiras. Caule suberoso. Ramos cilíndricos, entrenós 7,6-13,5 cm de compr. Pseudoestípulas presentes, orbiculadas, papirácea, $1,5 \times 1,8 \mathrm{~cm}$. Pecíolo 4-5,2 cm de compr. glabro; lâmina amplamente oval, 6,1-8 × 5,8-7,9 cm, papirácea, face adaxial glabra, face abaxial glabra, base cordada (sinus ca. $1 \mathrm{~cm}$ de profundidade), não peltados, ápice agudo, venação primária basal
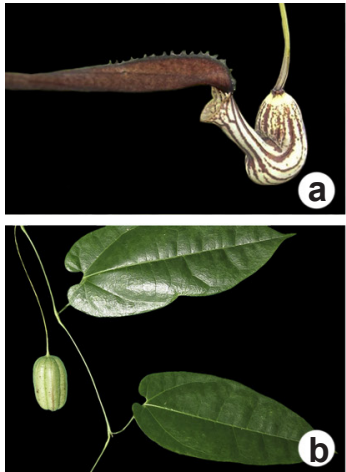

b
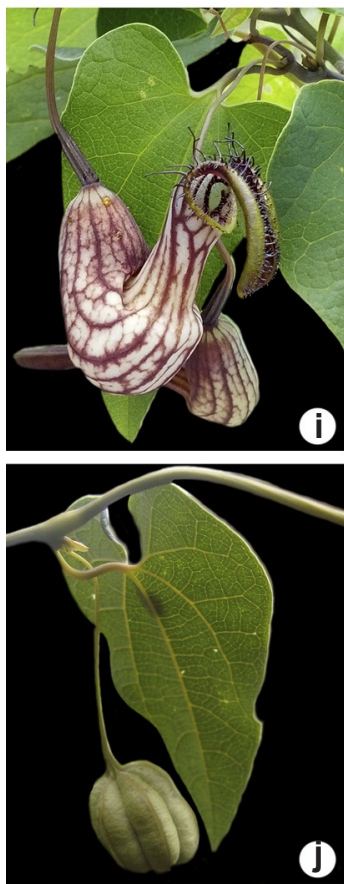
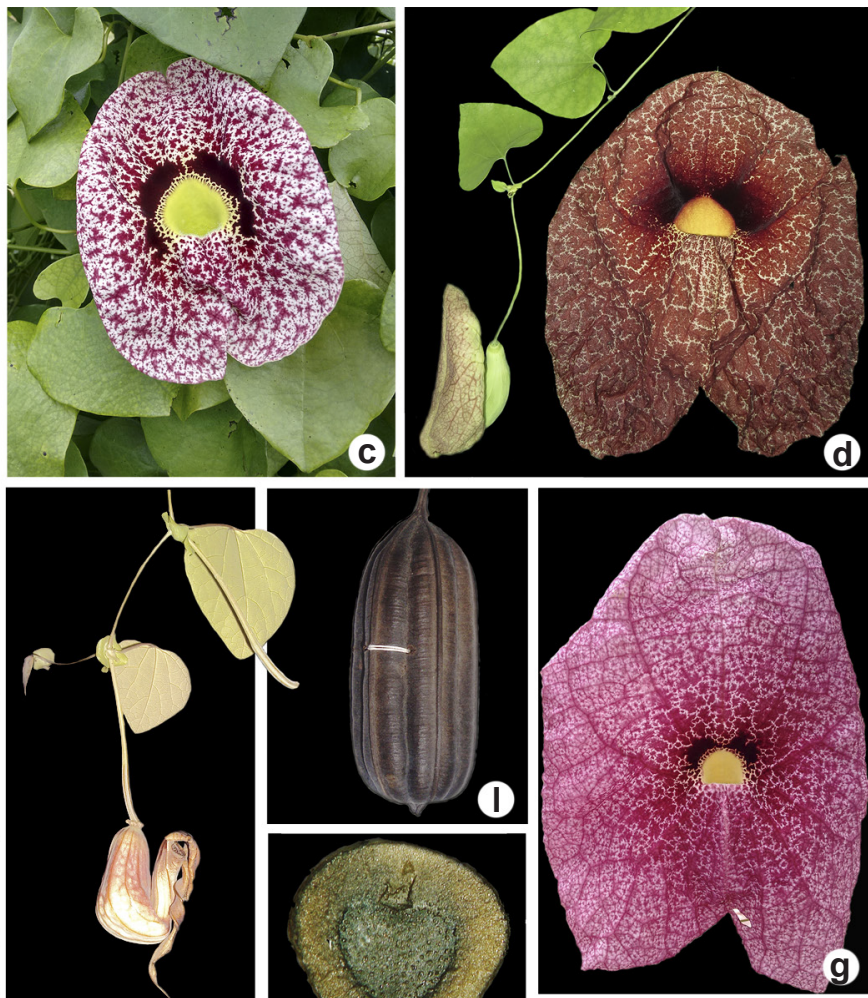

(i)
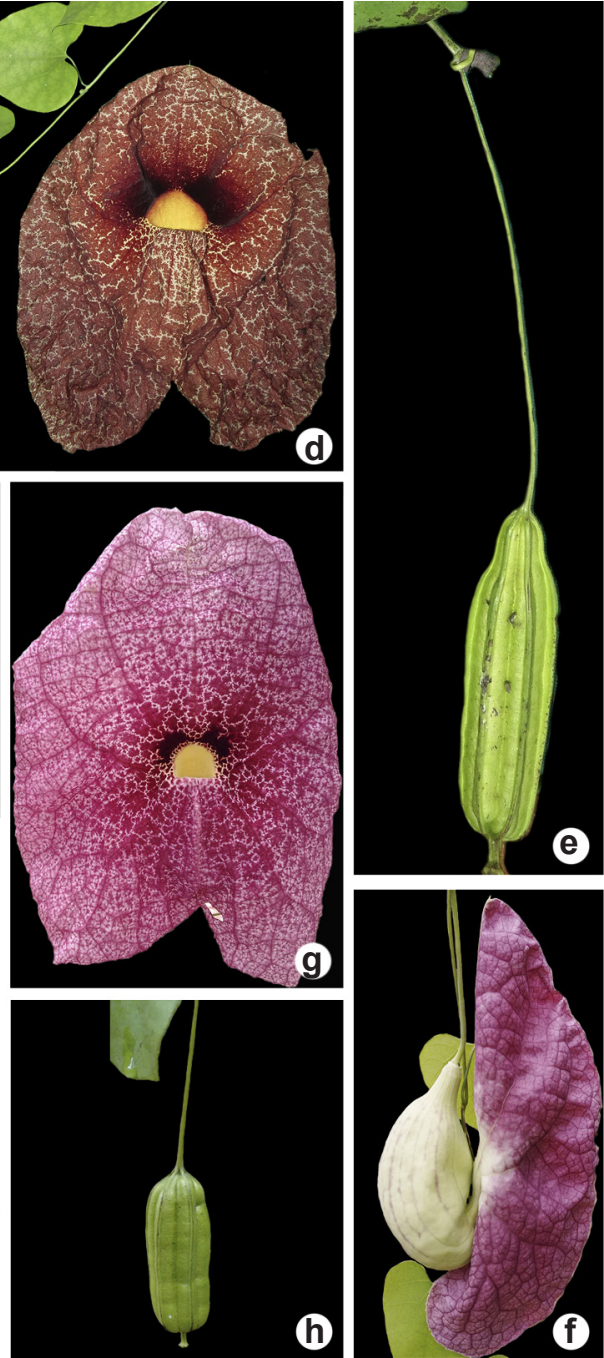

Figura 13 - a,b. Aristolochia cynanchifolia - a. flor; b. fruto. c. Aristolochia elegans - flor. d,e. Aristolochia gigantea - d. ramo florífero; e. fruto. f-h. Aristolochia aff. gigantea - f. ramo florífero; g. flor; h. fruto. i,j. Aristolochia gracilipedunculata - i. ramo florífero; j. ramo frutífero. k-n. Aristolochia hypoglauca - k. ramo florífero; 1. fruto; m. semente face adaxial; n. semente face abaxial. Fotos: a-h,j-n. Joelcio Freitas; i. Lucas de Almeida Silva.

Figure 13 - a,b. Aristolochia cynanchifolia - a. flower; b. fruit. c. Aristolochia elegans - flower. d,e. Aristolochia gigantea - d. floriferous branch; e. fruit. f-h. Aristolochia aff. gigantea - f. floriferous branch; g. flower; h. fruit. i,j. Aristolochia gracilipedunculata - i. floriferous branch; j. fructiferous branch. k-n. Aristolochia hypoglauca - k. floriferous branch; 1 . fruit; m. seed adaxial surface; $\mathrm{n}$. seed abaxial surface. Photos: a-h,j-n. Joelcio Freitas; i. Lucas de Almeida Silva. 
5(7). Inflorescências unifloras, não subtendidas por brácteas; Pedúnculo + ovário 16,9-18,3 cm de compr. Perianto glabro, pruinoso, bege com estrias lilases externamente; utrículo obovado, 7,3-8,2 $\times 3,8-4,4 \mathrm{~cm}$; siringe ca. $7 \mathrm{~mm}$, inequilátera; tubo funiforme, $2-2,4 \mathrm{~cm}$ compr. $\times 0,7-0,8 \mathrm{~cm}$ (proximal) - 1,6-1,8 cm (distal) diâm.; limbo unilabiado, amplamente oval, 15,9-17,5 × 13,5-14,7 cm, plano, amarelo próximo à entrada do tubo e lilás com estrias avermelhadas, fímbrias ausentes, base cordada, peltada, margem inteira, ápice arredondado, terminando num curto acúmen, $<1 \mathrm{~mm}$. Ginostêmio estipitado, $6 \mathrm{~mm}$ compr., estipite $<1 \mathrm{~mm}$ compr.; anteras lineares, $4 \mathrm{~mm}$ de compr. Cápsula estreito-cilíndrica, 6,4-7,3 $\times$ $2,1-2,2 \mathrm{~cm}$, veia média do mericarpo proeminente, $<1 \mathrm{~mm}$ de espessura, rostrada, rostro $0,8 \mathrm{~mm}$ de compr.; sementes amplamente ovais, $8 \times 6 \mathrm{~mm}$, planas, levemente verrucosas, não-aladas, rafe proeminente.

Material examinado: Afonso Cláudio, 3 pontões, 25.XII.2015, fl., E.J. Lírio et al. 1441 (MBML). Itarana, estrada para o Bananal, 15.II.2011, fl. C. Hencker et al. 61 (MBML). Laranja da Terra, rodovia ES-261, antes da Vila de Laranja da Terra, 26.XII.2015, fl., E.J. Lirio et al. 1442 (MBML). Localidade não específica, região Noroeste do estado, coletada por M. Peixoto em dezembro/1999 e floresceu em cultivo no sítio Primavera em, Biritiba Ussu, Mogi das Cruzes/SP, 25.II.2015, fl. e fr., J. Freitas 431 (MBML; VIES).

Aristolochia aff. gigantea é registrada para a Mata Atlântica, com ocorrência restrita para o ES, sendo encontrada em Floresta Ombrófila Densa (Fig. 15). Aristolochia aff. gigantea pertence à $A$. subsérie Hexandrae e é morfologicamente relacionada a $A$. elegans e $A$. gigantea. Foi considerada aqui como espécie a parte pelas suas características do limbo floral que a difere principalmente de A. gigantea (a discussão referente a morfologia de $A$. aff. gigantea e de suas espécies relacionadas estão nos comentários de $A$. elegans). Aristolochia aff. gigantea foi enquadrada pelos critérios da IUCN em Dados Deficientes (DD), devido à imprecisão taxonômica.

\section{Aristolochia gracilipedunculata $\mathrm{F}$. González,} Brittonia 63(4): 431. 2011. Figs. 11i,j; 13i,j

Trepadeiras com microscópicos pontos glandulares nos ramos, folhas e flores. Caule suberoso. Ramos cilíndricos, entrenós 6,5-18 $\mathrm{cm}$ de compr. Pseudoestípulas presentes, ovais, ligeiramente falcadas em vista lateral quando dobradas, $1-3 \times 1-2 \mathrm{~cm}$. Pecíolo $2-3,6 \mathrm{~cm}$ de compr., glabro; lâmina oval a estreitamente oval,
8-14 × 3,2-6,6 cm, membranácea, face adaxial e abaxial glabras, base cordada, (sinus ca. $4 \mathrm{~mm}$ de profundidade), não peltada, ápice agudo, venação primária basal 5(7). Inflorescências unifloras, não subtendidas por brácteas; Pedúnculo + ovário 6-17 cm de compr., filiforme, espessado no ápice. Perianto glabro, bege externamente com estrias vináceas espessadas; utrículo amplamente obovado, 1,6-2,3 × 0,7-0,9 cm; siringe ca. $2 \mathrm{~mm}$, inequilátera; tubo cilíndrico, 1,3-2,6 cm compr. $\times 0,5-0,7 \mathrm{~cm}$ (proximal) $-0,9-1,3 \mathrm{~cm}$ (distal) diâm; limbo unilabiado, oblongo a amplamente obovado, 1,8-2 × 1-1,5 cm, reflexo, marrom com fímbrias pretas em toda a margem, base truncada a emarginada, não peltada, margem revoluta, ápice arredondado a emarginado, terminando num curto acúmen, $<1 \mathrm{~mm}$. Ginostêmio estipitado, 4-6 mm compr., estípite $1 \mathrm{~mm}$ compr.; anteras oblongas, ca. $3 \mathrm{~mm}$ de compr. Cápsula curtamente cilíndrica, $1,6-2,5 \times 1-1,6 \mathrm{~cm}$, veia média do mericarpo proeminente, $<1 \mathrm{~mm}$ de espessura, não rostrada; sementes ovais, $6 \times 5 \mathrm{~mm}$, planas, face abaxial lisa a levemente verrucosa, face adaxial e margem verrucosas, não-aladas, rafe proeminente.

Material examinado: Águia Branca, Santa Luzia, propr. Ciro Ferreira, 20.XII.2007, fl. e fr., V. Demuner et al. 4834 (MBML). Santa Luzia, propr. Ciro Ferreira, 3.IV.2007, fr., V. Demuner et al. 3517 (MBML); assentamento 16 de Abril, 10.III.2015, fl., J. Freitas et al. 363 (MBML; VIES). Barra de São Francisco, Córrego da Poaia, Fazenda Santa Cruz, 13.XII.2000, fl., L. Kollmann \& E. Bausen 3537 (MBML). Colatina, Alto Moacir, Pedra do Cruzeiro, 17.IV.2006, fl. e fr., L.F.S. Magnago et al. 803 (MBML). Governador Lindenberg, propr. Firmino Sotele, próximo a Pedra de Santa Luzia, 19.XI.2014, fl e fr., J. Freitas \& L.A. Silva 295 (MBML; VIES).Pancas, Trilha da Pedra da Colina, 7.VII.2015, fl e fr., J. Freitas et. al. 417 (VIES). Santa Leopoldina, Bragança, Rancho Chapadão, propr. João Emilio, 30.III.2006, fl., V. Demuner et al. 2119 (MBML). Santa Teresa, São João de Petrópolis, Barra de Santo Hilário, Paulo Zanette, 10.V.2000, fr., V. Demuner et al. 1008 (MBML).

Aristolochia gracilipedunculata, representante de $A$. subsérie Hexandrae, tem distribuição restrita à Mata Atlântica, para os estados da Bahia e Espírito Santo (BFG 2015). No ES, é registrada para as florestas ombrófila submontana e estacional semidecidual (Fig. 15), quase sempre associada à ambientes rochosos. Dentre as espécies capixabas, é morfologicamente próxima a $A$. nevesarmondiana, porém difere desta pela folha oval a estreitamente oval de base cordada (vs. lâmina deltoide de base truncada a 
subcordada) e pelo limbo oblongo a amplamente obovado com margem fimbriada ( $v s$. amplamente elíptico a suborbicular e margem não fimbriada). Aristolochia gracilipedunculata pode ser considerada Menos preocupante (LC) de acordo com os critérios da IUCN (2015), devido à sua ampla distribuição no estado do ES.

11. Aristolochia hypoglauca Kuhlmann, Arq. Inst. Biol. Veg. 3: 45. 1936. Figs. 11k-m; 13k-n

Trepadeiras. Caule suberoso. Ramos cilíndricos, entrenós 5,4-16 cm de compr. Pseudoestípulas presentes, orbiculadas, cartáceas, 1,5-2 cm compr. Pecíolo 3,9-9,5 cm de compr. pubérulo; lâmina amplamente oval, 6,6-15 × $7,7-16 \mathrm{~cm}$, papirácea a cartácea, face adaxial glabra, face abaxial pubérula e glauca, base truncada ou ligeiramente cordada (sinus ca. $3 \mathrm{~mm}$ de profundidade), não peltados, ápice obtuso a arredondado, venação primária basal 3(5). Inflorescências unifloras, não subtendidas por brácteas; Pedúnculo + ovário $8,3-23 \mathrm{~cm}$ de compr. Perianto glabro, pruinoso, bege, externamente com estrias vinaceas delgadas; utrículo amplamente obovado, 4,1-8 × 2,2-4 cm; siringe ca. $5 \mathrm{~mm}$, inequilátera; tubo funiforme, $2,1-3,6 \mathrm{~cm}$ compr. $\times 0,9 \mathrm{~cm}$ (proximal) $-2 \mathrm{~cm}$ (distal) diâm; limbo unilabiado, 20-35 × 2-3 $\mathrm{cm}$ de compr., convexo, bege com estrias pretas muito finas, fímbrias ausentes, base cordada, peltada, lanceolado, retorcido no $1 / 3$ basal, margem inteira, ápice agudo, acúmen ausente. Ginostêmio estipitado, 8-12 mm compr., estípite ca. $2 \mathrm{~mm}$ compr.; anteras oblongas, $7 \mathrm{~mm}$ de compr. Cápsula cilíndrica a estreito-cilíndrico, $4,6-6,1 \times 1,5-2,5 \mathrm{~cm}$, veia média do mericarpo proeminente, $1 \mathrm{~mm}$ de espessura, rostrada, rostro ca. 3-4,5 mm de compr.; sementes ovais, 7,5 $\times 7$ $\mathrm{cm}$, planas, verrucosas, não aladas, rafe ausente. Material examinado: Fundão, Goiapabaçu, 18.III.2005, fl. e fr., L. Kollmann et al. 7468 (MBML); 16.III.2006, fl. e fr., L. Kollmann et al. 8749 (MBML). João Neiva, Alto Bergano, 4.X.2007, fl., L. Kollmann et al. 10162 (MBML). Santa Leopoldina, Encantado, propr. Sra. Zenith Zani, 17.I.2007, fl., J. Rossini \& L.C. Rossini 584 (MBML); Fazenda Caioaba, Trilha do Córrego Caioaba, 8.VIII.2006, fl. e fr., L.F.S. Magnago 1221 (MBML). Santa Maria de Jetibá, São José do Rio Claro, propr. Alfredo Renok, 21.I.2009, f1., J. Freitas 02 (MBML); 17.II.2013, fl. e fr., J. Freitas \& I.G.V. Freitas 188 (MBML); 23.XII.2013, fl., J. Freitas \& L. Tonini 197 (MBML). Santa Teresa, distrito de 25 de Julho, localidade Bela Vista, fl., 20.VI.2005, A.P. Fontana \& C. Esgario 1345 (MBML); Rio Saltinho, terreno de Tranhago, 4.IX.2001, fl., L. Kollmann et al. 4495 (MBML); antes do terreno do Tranhago, na rodovia sentido Santa Teresa-Fundão, 9.I.2013, fl., E.J. Lirio et al. 683 (MBML); RPPN Vale do Sol, 17.X.2014, fl., P.J. Coelho et al. 38 (MBML). Município desconhecido, localidade de Três Ilhas, margens do Rio Doce, sem data, fl., J.G. Kuhlmann 238 (RB);

Restrita à Mata Atlântica, endêmica para o Espírito Santo (BFG 2015). É registrada para as florestas ombrófila densa montana e submontana (Fig. 15), em borda de florestas ou estradas, às vezes associada a ambientes úmidos. Aristolochia hypoglauca, representante de $A$. subsérie Hexandrae, é morfologicamente relacionada a Aristolochia trilobata, devido à presença de pseudoestípulas e pelo limbo caudado. Difere desta espécie, porém,pela folha amplamente oval (vs. trilobada em A. trilobata). Aristolochia hypoglauca pode ser considerada Em Perigo (EN) de acordo com os critérios da IUCN $(2010,2015)$ : $\mathrm{B} 1 \mathrm{ab}(\mathrm{ii})$, com $\mathrm{EOO}=591 \mathrm{~km}^{2}$.

12. Aristolochia labiata Willd., Mém. Soc. Imp. Naturalistes Moscou 2: 101-102. 1809.

Figs. 14a; 16a

Trepadeiras. Caule suberoso. Ramos cilíndricos, entrenós 8,6-16,5 $\mathrm{cm}$ de compr. Pseudoestípulas presentes, amplamente ovais, 2,4-2,6 × 2,4-2,8 cm. Pecíolo 3,5-13 cm de compr., glabro; lâminas orbiculares, 9-22,5 × 9,2$20,7 \mathrm{~cm}$, membranáceas a papiráceas, face adaxial glabra e abaxial glabra, base profundamente cordada (sinus 1,5-6,2 cm de profundidade), não peltada, ápice arredondado a obtuso, venação primária basal 3(5). Inflorescências unifloras não subtendidas por brácteas. Pedúnculo + ovário 7,2$15,7 \mathrm{~cm}$ de compr. Perianto glabro, bege a branco com estrias vináceas a enegrecidas; utrículo obovado, 5,1-6,8 × 3,7-4,1 cm; siringe ca. 5 $\mathrm{mm}$, inequilátera; tubo funiforme, $0,7-3,4 \mathrm{~cm}$ compr. $\times 1,3-0,9 \mathrm{~cm}$ (proximal) $-1,9 \mathrm{~cm}$ (distal) diâm; limbo bilabiado, côncavo, bege com estrias vináceas, base peltada; lábio superior obovado, 10,5-13 × 8,6-15 cm, fímbrias ausentes, base unguiculada, margem inteira, ápice obcordado, acúmen ausente; lábio inferior carenado, 4,8-7,6 $\times 1,6-2,2 \mathrm{~cm}$, margem inteira, ápice mucronulado. Ginostêmio não-estipitado, ca. $7 \mathrm{~mm}$; anteras oblongas, ca. $4 \mathrm{~mm}$ de compr. Cápsula estreitocilíndrica, $7,5 \times 3 \mathrm{~cm}$, veia média do mericarpo proeminente, $<1,5 \mathrm{~mm}$ de espessura, rostrada, rostro ca. $2 \mathrm{~mm}$ de compr. Sementes ovais, 1,4 $\times$ $1 \mathrm{~cm}$, planas, verrucosas, não-aladas, rafe ausente. 


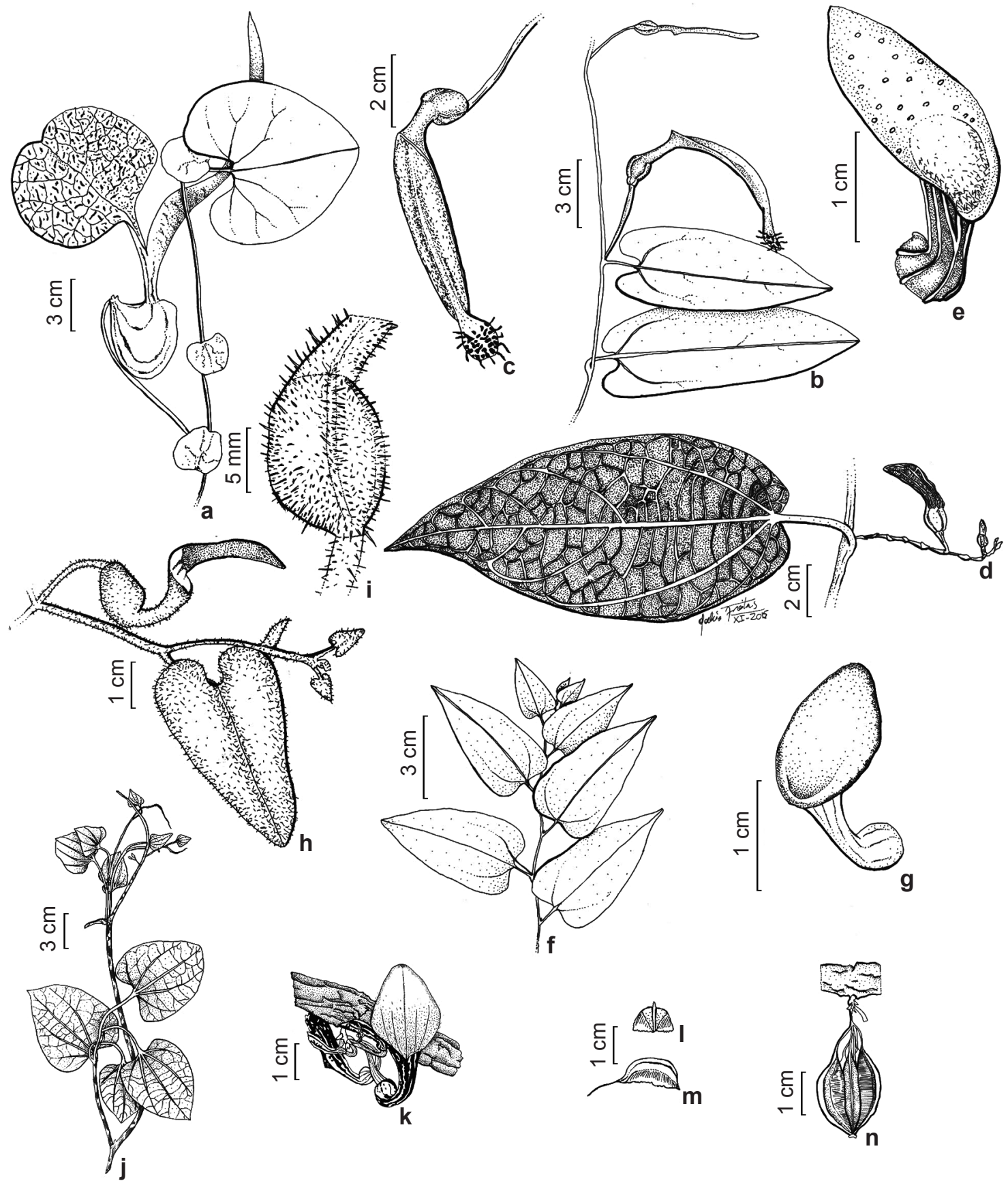

Figura 14 - a. Aristolochia labiata - ramo florífero. b,c. Aristolochia longispathulata - b. ramo florífero; c. flor. d,e. Aristolochia melastoma - d. ramo florífero; e. flor. f,g. Aristolochia nevesarmondiana - f. ramo; g. flor. h,i. Aristolochia pubescens - h. ramo florífero; i. utrículo com indumento externo. j-n. Aristolochia subglobosa - j. ramo; k. caule suberoso com racemo; $1, \mathrm{~m}$. mericarpo do fruto -1 . vista frontal; $\mathrm{m}$. vista lateral; $n$. caule suberoso com fruto. Figure 14 - a. Aristolochia labiata - floriferous branch. b,c. Aristolochia longispathulata - b. floriferous branch; c. flower. d,e. Aristolochia melastoma - d. floriferous branch; e. flower. f,g. Aristolochia nevesarmondiana - f. branch; g. flower. h,i. Aristolochia pubescens - $\mathrm{h}$. floriferous branch; i. utricle with external indument. j-n. Aristolochia subglobosa - j. branch; k. corky stems with cauliflorous raceme; 1,m. fruit mericarp -1 . frontal view; $m$. side view; $n$. corky stems with fruit. 
Material examinado: Domingos Martins, sem data, fl., R. Kautsky 963 (RB). Pinheiros, REBIO Córrego do Veado, 30.V.2008, fl., L. Kollmann \& L.F.S. Magnago 11052 (MBML). Santa Teresa, Valão de São Lourenço, Estação Biológica da Caixa d'Água, 25.II.1991, fl., E. Bausen 10 (MBML). São Mateus, Palmitinho, 2.XII.2004, fl., L.A. Vieira (MBML).

Material adicional examinado: BRASIL. BAHIA: Entre Rios, estrada para Imbé, 20.I.2007, fl. e fr., T.S. Nunes 1763 (HUEFS).

Aristolochia labiata tem ampla distribuição para diversos estados da Mata Atlântica, Cerrado e Caatinga (BFG 2015). No ES, é encontrada em florestas Ombrófila Densa Montana e de tabuleiro (Fig. 15), geralmente próximo à borda de floresta. Aristolochia labiata pertence à $A$. subsérie Hexandrae e é semelhante a $A$. cymbifera, porém difere dela pela base do limbo superior unguiculado (vs. cimbiforme). As duas espécies são muito similares vegetativamente e em frutificação, sendo difícil a separação das entidades na ausência de flores. Aristolochia labiata pode ser considerada Menos preocupante (LC) de acordo com os critérios da IUCN (2015), devido à sua ampla distribuição.
13. Aristolochia longispathulata F. González, Novon, 10(4): 371. 2000. Figs. 14b,c; 16b,c

Trepadeiras. Caule suberoso. Ramos cilíndricos, entrenós 5,8-18,2 cm de compr. Pseudoestípulas ausentes. Pecíolo 1,9-3,2 cm de compr., glabro; lâmina estreito-oval, 8-16 × 3-4,5 $\mathrm{cm}$, papirácea, face adaxial glabra com corpos silicosos, face abaxial pubérula, base cordada, (sinus 5-16 mm de profundidade), peltada, ápice obtuso, venação primária basal 3(5). Inflorescências unifloras, não subtendidas por brácteas. Pedúnculo + ovário 1,3-2,7 cm de compr. Perianto pubérulo, bege à vináceo externamente com estrias vináceas proeminentes; utrículo oval, $0,7-1,1 \times 0,5-0,7$ $\mathrm{cm}$; siringe ca. $1 \mathrm{~mm}$, inequilátera; tubo oblongo, levemente ampliado no ápice, 1,1-1,3 cm compr. $\times 0,4 \mathrm{~cm}$ (proximal) - 0,6-0,7 (distal) diâm; limbo unilabiado, estreito-oblongo, 5,7-7 × 0,9-1,2 cm, convexo em quase todo o comprimento, $4 / 5$ basal verde claro com tricomas esbranquiçados, o restante branco com manchas vináceas e fímbrias negras no ápice, base obtusa, peltada, margem inteira, ápice espatulado, acúmen ausente. Ginostêmio não estipitado, ca. $4 \mathrm{~mm}$ de compr., estipite ca. 1

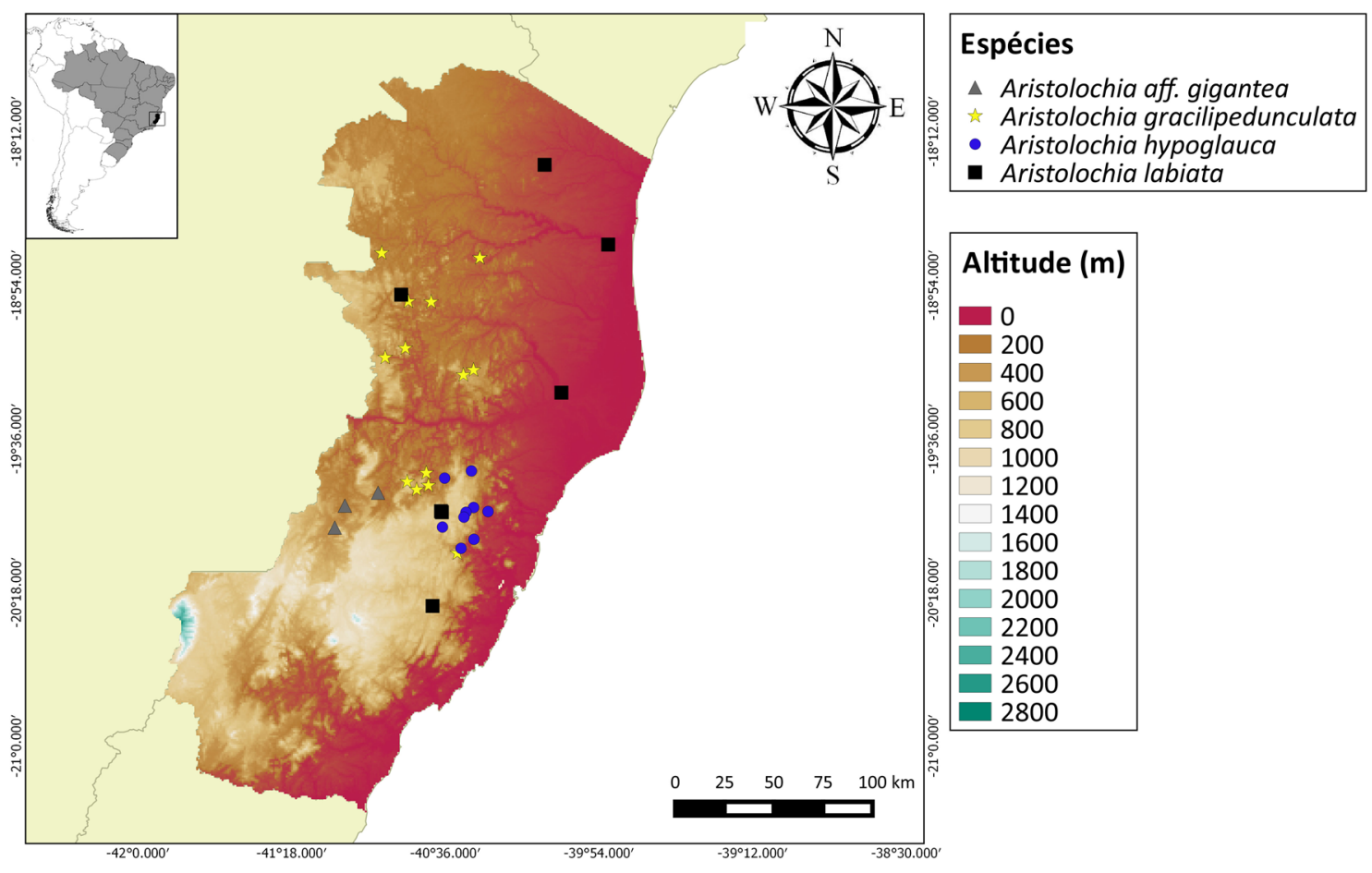

Figura 15 - Mapa de distribuição geográfica com camada altitudinal no estado do Espírito Santo - Aristolochia aff. gigantea ( $\mathbf{\Delta})$; Aristolochia gracilipedunculata $(\star)$; Aristolochia hypoglauca $(\bullet)$; Aristolochia labiata $(\boldsymbol{\square})$.

Figure 15 - Map of geographic distribution with altitudinal layer in Espírito Santo state, Brazil - Aristolochia aff. gigantea ( $\mathbf{\Delta})$; Aristolochia gracilipedunculata ( $\star$ ); Aristolochia hypoglauca $(\bullet)$; Aristolochia labiata (ロ). 

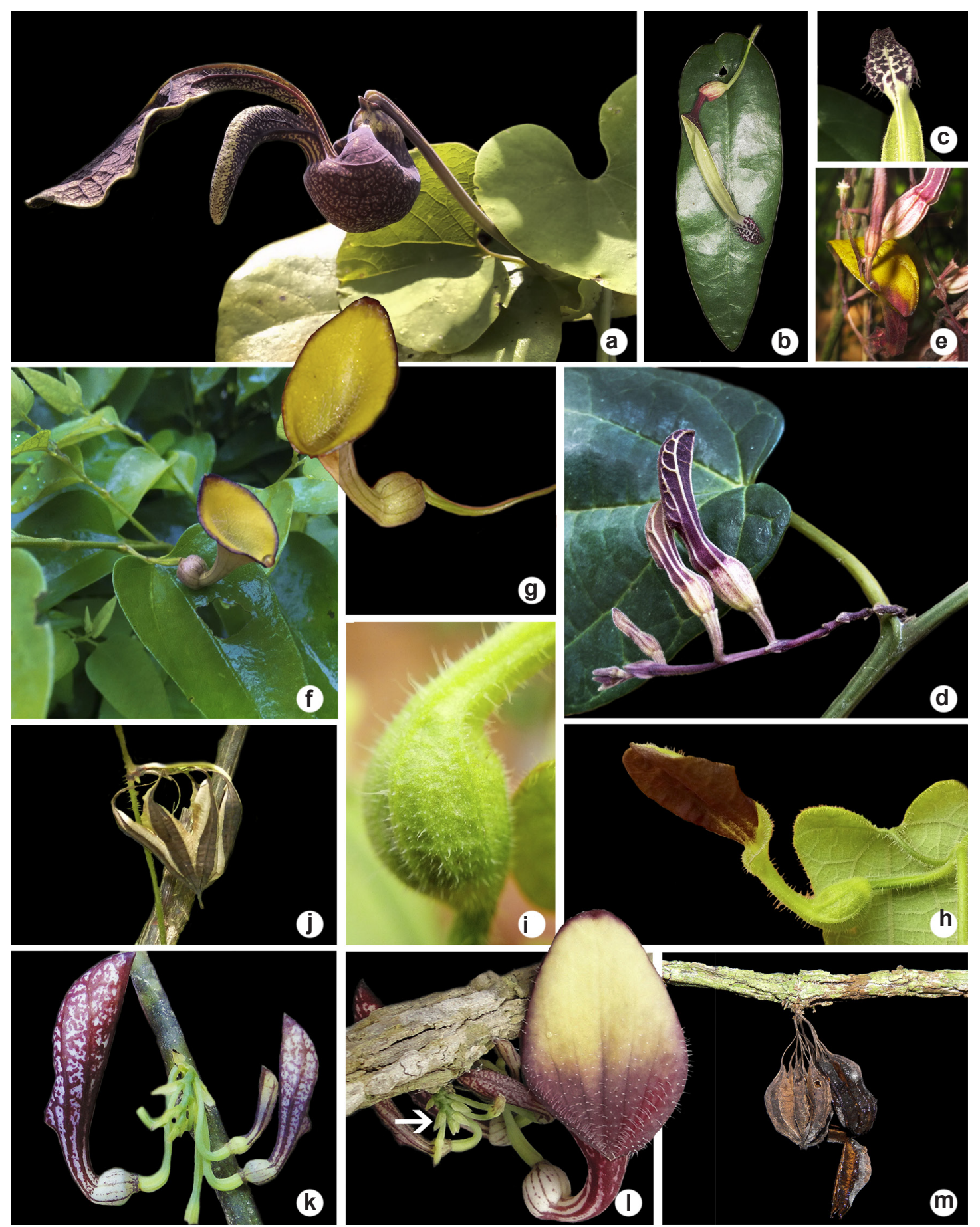

Figura 16 - a. Aristolochia labiata - ramo florífero. b,c. Aristolochia longispathulata - b. folha e flor; c. detalhe do ápice espatulado e fimbriado. d,e. Aristolochia melastoma - d. ramo florífero; e. flor. f,g. Aristolochia nevesarmondiana - f. ramo florífero; g. flor. h-j. Aristolochia pubescens - h. flor; i. detalhe da pilosidade no utrículo; j. fruto. k-m. Aristolochia subglobosa - k. botões; 1. caule suberoso com racemo; m. fruto. Fotos: a-d,f-h,j-m. Joelcio Freitas; e. Idimá Gonçalves; i. Lucas de Almeida Silva; m. Michel Ribeiro.

Figure 16 - a. Aristolochia labiata - floriferous branch. b,c. Aristolochia longispathulata - b. leaf and flower; c. detail of the spatulate and fimbriate apex. d,e. Aristolochia melastoma - d. floriferous branch; e. flower. f,g. Aristolochia nevesarmondiana - f. floriferous branch; g. flower. h-j. Aristolochia pubescens - h. flower; i. detail of utricle indumentum; j. fruit. k-m. Aristolochia subglobosa - k. buds; 1. corky stems with cauliflorous raceme; m. fruit. Photos: a-d,f-h,j-m. Joelcio Freitas; e. Idimá Gonçalves; i. Lucas de Almeida Silva; m. Michel Ribeiro. 
mm compr.; anteras oblongas, ca. $2 \mathrm{~mm}$ de compr. Cápsula não observada.

Material examinado: Governador Lindenberg, propr. Frimino Sotele, próximo a Pedra de Santa Luzia, 19.XI.2014, fl., J. Freitas \& L.A. Silva 292 (MBML); 7.XI.2007, fl., V. Demuner et al. 4498 (MBML). Pancas, propr. Juliberto, 7.VII.2015, fr., J. Freitas et al. 422 (VIES).

Restrita à Mata Atlântica, A. longispathulata é encontrada apenas para o estado da Bahia (BFG 2015) sendo este o primeiro registro para o Espírito Santo. No ES, é encontrada nas Florestas Estacional e Ombrófila (Fig. 17), geralmente associada à afloramentos rochosos e próxima a áreas antropizadas. Aristolochia longispathulata é representante de $A$. subsérie Hexandrae e semelhante a $A$. arcuata, porém difere desta pelo limbo convexo em quase todo o comprimento, ápice espatulado e comprimento de 5,7-7 cm ( $v s$. côncavo de ápice arredondado e 3,3-3,7 cm de comprimento). Aristolochia longispathulata foi enquadrada na categoria Em perigo (EN) de acordo com os critérios da IUCN (2010, 2015): B2b(ii), $\operatorname{com} \mathrm{AOO}=8 \mathrm{~km}^{2}$ ).

14. Aristolochia melastoma Silva Manso ex Duch., Prodr.15(1): 460. 1864. Figs. 14d,e; 16de

Trepadeiras. Caule suberoso. Ramos cilíndricos, entrenós 6,5-13,3 cm de compr. Pseudoestípulas ausentes. Pecíolo 2,2-4,6 cm de compr., pubescente na base, com zona basal de abscisão; lâmina estreitamente oval a lanceolada, $12-15 \times 5,4-6,8 \mathrm{~cm}$, papirácea, face adaxial glabra, face abaxial glabrescente a pilosa, base levemente cordada (sinus 4-8 mm de profundidade), peltada, ápice atenuado a acuminado, venação primária basal 3(5). Inflorescências em racemos axilares, 3,5-4,6 cm de compr., ca. 8 flores, entrenós $>5$ mm compr., subtendidos por brácteas estreitoovais, $3 \times 1,5 \mathrm{~mm}$, sésseis, face abaxial pilosa, face adaxial glabra. Pedúnculo + ovário 0,4-0,6 cm de compr, com zona basal de abscisão. Perianto pubescente, vináceo externamente com estrias beges a avermelhadas proeminentes; utrículo amplamente obovado, 9-11 × $6 \mathrm{~mm}$; siringe ca. 1,5 mm compr., equilátera; tubo funiforme, $0,7-0,8$ $\mathrm{cm}$ de compr. $\times 0,45 \mathrm{~cm}$ (proximal) $-0,4-0,45$ cm (distal) diâm., entumescido na base; limbo unilabiado, amplamente oval a oval, 1,9-2,3 $\times$ 1,3-1,4 cm, côncavo, amarelado a alaranjado com superfície verrucosa e tricomas esbranquiçados, fímbrias ausentes, base obtusa, peltada, margem inteira, ápice obtuso, acúmen ausente. Ginostêmio estipitado, ca. 3,5 mm de compr., estípite $<1 \mathrm{~mm}$ compr.; anteras ca. 1,5 mm de compr. Cápsula não observada.

Material examinado: Águia Branca, Assentamento 16 de Abril, 16.III.2006, fl., V. Demuner et al. 2034 (MBML); 10.III.2015, fl., J. Freitas et al. 367 (MBML; VIES).

Aristolochia melastoma tem ocorrência na Mata Atlântica, Cerrado e Amazônia, para todo o Centro-Oeste, e nos estados do Pará, Paraná, Rio de Janeiro, São Paulo e Minas Gerais (BFG 2015). Constitui um novo registro para o ES, e foi encontrada em Floresta Estacional (Fig. 17) em borda de mata alterada. Aristolochia melastoma é a única representante de $A$. série Thyrsicae no ES. Ela difere das demais espécies pela sua inflorescência em tirsos ( $v s$. flores isoladas ou em racemos nas demais), e pela superfície verrucosa do limbo ( $v s$. liso nas demais). Aristolochia melastoma pode ser considerada Criticamente Ameaçada (CR) de acordo com os critérios da IUCN (2010, 2015): $\mathrm{A} 2 \mathrm{c}, \mathrm{B} 2 \mathrm{ab}(\mathrm{ii}, \mathrm{iii}) \mathrm{com} \mathrm{AOO}=4 \mathrm{~km}^{2}$.

15. Aristolochia nevesarmondiana Hoehne, Arch. Bot. Sao Paulo 1: 7. $1925 . \quad$ Figs. 14f,g; 16f,g Ervas prostradas a trepadeiras. Caule suberoso ausente. Ramos cilíndricos, entrenós 1,2-5,5 cm de compr. Pseudoestípulas presentes, amplamente ovais, $0,5 \times 0,7 \mathrm{~cm}$, frequentemente caducas. Pecíolo ca. 0,5 cm de compr. pubérulo; lâmina deltóide, 2,7-4,6 × 1,3-2,1 cm, papirácea, face adaxial glabra, face abaxial pubérula, base truncada a subcordada (sinus ca. 0,2 cm de profundidade), não peltados, ápice agudo, venação primária basal 3(5). Inflorescências unifloras, não subtendidas por brácteas. Pedúnculo + ovário 1,6-1,8 cm de compr. Perianto glabrescente, esverdeado externamente com estrias verdes a vináceas; utrículo orbicular a subgloboso, 4,5-5,8 × 4,5-6 $\mathrm{mm}$; siringe ca. $1 \mathrm{~mm}$, inequilátera; tubo funiforme, $1,1-1,2 \mathrm{~cm}$ compr. $\times 0,2-0,25 \mathrm{~cm}$ (proximal) $-0,8 \mathrm{~cm}$ (distal) diâm); limbo unilabiado, amplamente elíptico a suborbicular, 1,3-1,5 × 1-1,25 cm, côncavo, amarelo com tricomas brancos, fímbrias ausentes, base obtusa, peltada, margem revoluta, ápice obtuso a retuso, acúmen ausente. Ginostêmio estipitado, ca. 2,5 mm de compr., estipe ca. 1 mm compr.; anteras ca. $1 \mathrm{~mm}$ de compr. Cápsula curtamente cilíndrica, 1,7-1,9 ×0,9 cm, veia média do mericarpo proeminentes, $<1 \mathrm{~mm}$ de espessura, rostrada, rostro ca. $2 \mathrm{~mm}$ de compr. Sementes amplamente ovais, $4 \times 3 \mathrm{~mm}$, côncavo-convexas, face abaxial lisa, face adaxial verrucosa, nãoaladas, rafe proeminente na base. 
Material examinado: Colatina, Reserva Biológica de Itapina, 12.IV.2007, fl., R.C. Brito et al. 218 (MBML). Barra de São Francisco, Parque Municipal Sombra da Tarde, 22.XI.2000, fr., L. Kollmann et al. 3325 (MBML). Nova Venécia, Pedra do Elefante, 18.V.2015, fr., N.T.L. Pena 269 (VIES).

Material adicional examinado: BRASIL. MINAS GERAIS: Carangola, Serra do Papagaio, 6.III.2008, fl., L.S. Leoni 7099 (MBML).

Possui distribuição restrita à Mata Atlântica, para os estados da São Paulo e Rio de Janeiro (BFG 2015), sendo este o primeiro registro para o estado. No ES, é registrada para a Floresta Estacional Semidecidual (Fig. 17). Aristolochia nevesarmondiana é representante de $A$. subsérie Hexandrae, sendo semelhante a $A$. pubescens. Difere desta espécie por apresentar flores com superfície glabrana face externa, pelo limbo peltado e pela base da folha truncada ( $v s$. superfície hirsuta, limbo não peltado e base da folha cordada em $A$. pubescens). Aristolochia nevesarmondiana pode ser considerada Em Perigo (EN) de acordo com os critérios da IUCN $(2010,2015)$ : B1(i, ii, iii) + $2 \mathrm{ab}(\mathrm{i}, \mathrm{ii}, \mathrm{iii}) \operatorname{com} \mathrm{EOO}=2023 \mathrm{~km}^{2}$ e $\mathrm{AOO}=12 \mathrm{~km}^{2}$.
16. Aristolochia pubescens Willd. ex Duch., Prodr. [A. P. de Candolle] 15(1): 450. 1864.

Figs. 14h-i; 16h-j

Ervas prostradas a trepadeiras. Caule suberoso ausente. Ramos cilíndricos, entrenós 5,5-8,9 cm de compr. Pseudoestípulas ausentes. Pecíolo 1,5-3,3 cm de compr., híspido; lâmina oval, 4,4-7 ×2,4-5 cm, membranácea a papirácea, face adaxial hirsuta, face abaxial pubescente, base cordada (sinus ca. 0,7-1,2 cm de profundidade), não peltados, ápice obtuso, venação primária basal 5(7). Inflorescências unifloras, não subtendidas por brácteas. Pedúnculo + ovário $0,9-2,1 \mathrm{~cm}$ de compr. Perianto hirsuto, verde claro com estrias verdes proeminentes; utrículo oval a estreitooval, $0,8-1,23 \times 0,4-0,8 \mathrm{~cm}$; siringe $<1 \mathrm{~mm}$, inequilátera; tubo funiforme, $0,75-1,3 \mathrm{~cm}$ compr. $\times 0,35 \mathrm{~cm}$ (proximal) $-0,8 \mathrm{~cm}$ (distal) diâm.; limbo unilabiado, 1,4-2,6 × 1,1-1,8 cm, plano a levemente convexo, vináceo a esverdeado, frequentemente com estrias vináceas na base, glabro, base obtusa, não peltada, margem inteira, ápice retuso, acúmen ausente. Ginostêmio estipitado, 2,5-4,2 mm, estipe $<$ 1,5 mm compr.; anteras oblongas, ca. $1 \mathrm{~mm}$ de

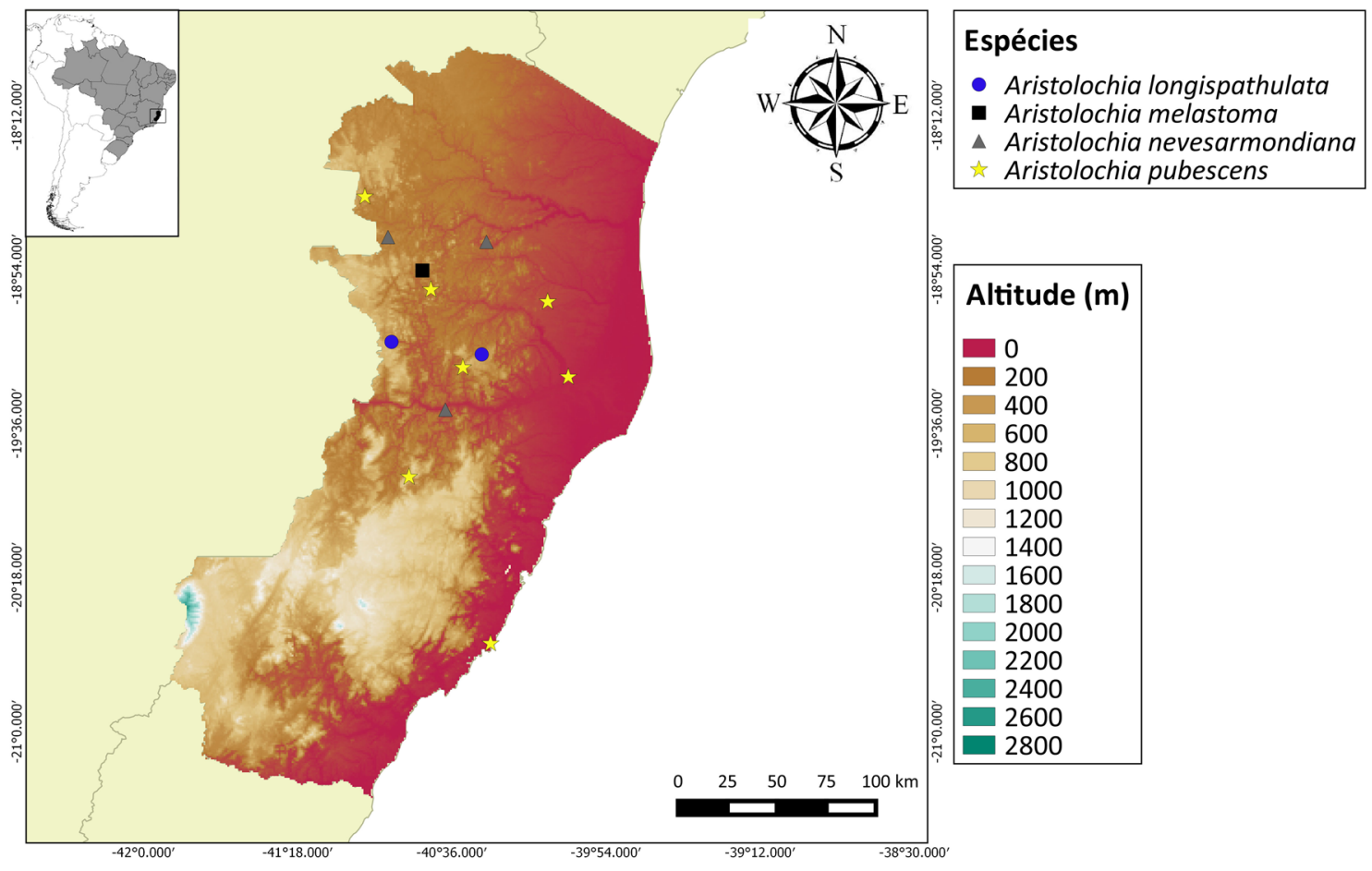

Figura 17 - Mapa de dstribuição geográfica com camada altitudinal no estado do Espírito Santo - Aristolochia longispathulata $(\bullet)$; Aristolochia melastoma $(\boldsymbol{\bullet})$; Aristolochia nevesarmondiana $(\boldsymbol{\Delta})$; Aristolochia pubescens $(\star)$. Figure 17 - Map of geographic distribution with altitudinal layer in Espírito Santo state, Brazil - Aristolochia longispathulata (•); Aristolochia melastoma (ם); Aristolochia nevesarmondiana $(\mathbf{\Delta})$; Aristolochia pubescens $(\star)$. 
compr. Cápsula cilíndrica, 2,9-3,3 × 1,25 cm, veia média do mericarpo proeminente, ca. $1 \mathrm{~mm}$ de espessura, rostrada, rostro 4-5 $\mathrm{mm}$ de compr.; sementes amplamente ovais, $4 \times 3 \mathrm{~mm}$, côncavoconvexas, verrucosas, não aladas, rafe proeminente com duas excrescências laterais.

Material examinado: Água Doce do Norte, estrada para a torre da Vivo, 25.IX.2014, fr., J. Freitas et al. 260 (MBML; VIES). Águia Branca, propr. Zé Alemão, 10.III.2015, fl., J. Freitas et al. 368, 369 (MBML; VIES). Guarapari, Praia de Setiba, 15.II.2015, fl., J. Freitas \& L. Tonini 361 (MBML; VIES). Linhares, Reserva Natural da Vale, 9.III.1993, fl., G.L. Farias 602 (CVRD; MBML; RB).

Aristolochia pubescens tem distribuição restrita à Mata Atlântica, apenas para a Bahia (BFG 2015), sendo este o primeiro registro para o estado. No ES, é registrada para a Restinga, Tabuleiro e Floresta Estacional Semidecidual (Fig. 17). A espécie pertence à $A$. subsérie Hexandrae, sendo morfologicamente semelhante a $A$. nevesarmondiana, diferindo desta espécie pela superfície hirsuta da face externa das flores, pela base da folha cordada e pelo limbo não peltado (vs. superfície glabra, base da folha truncada e pelo limbo peltado em $A$. nevesarmondiana). Aristolochia pubescens foi enquadrada pelos critérios da IUCN em Vulnerável (VU) de acordo com os critérios da IUCN $(2010,2015)$ : B1b(i, iii) com $\mathrm{EOO}=11493 \mathrm{~km}^{2}$.

17. Aristolochia subglobosa J. Freitas, Lírio \& F. González, Phytotaxa, 124: 55. 2013.

Figs. 14j-n; 16k-m

Trepadeiras. Caule suberoso. Ramos cilíndricos, entrenós ca. 7,5 cm de compr. Pseudoestípulas ausentes. Pecíolo 3,6-7,2 cm de compr., a metade proximal um pouco mais espessado, glabro; lâmina oval-deltóide, 9-23 $\times$ 4,1-10,8 cm, cartácea, glabra, base truncada ou ligeiramente cordada (com um sinus ca. 1,1 cm de profundidade), não peltada, ápice agudo a acuminado, venação primária basal 3(5). Inflorescências em racemos caulifloros curtos, 7-10 mm compr. cada, 8-11 flores, entrenós $<1$ mm compr., subtendidos por brácteas deltóides, $2-2,5 \times 1,8-2 \mathrm{~mm}$, púberulas nas margens. Pedúnculo + ovário 0,8-1,5 cm compr, pubescente. Perianto glabro, bege externamente com estrias vináceas espessadas; utrículo ovóide, 4-6 × 5-6 $\mathrm{mm}$; siringe inequilátera, 1,5-1,8 mm compr.; tubo funiforme, $0,8-1,5 \mathrm{~cm}$ compr. $\times 2-2,2 \mathrm{~mm}$ (proximal) - 7-14 mm (distal) diâm.; limbo unilabiado, amplamente elíptico a obovado, 2,2-
$2,9 \times 1,3-1,7 \mathrm{~cm}$, com a parte superior quase plana, vináceo na base e o restante amarelo, com estrias vináceas delgadas, 2/3 inferior piloso, o restante glabro, fímbrias ausentes, base emarginada, não peltada, margem ligeiramente ondulada, ápice obtuso, terminando num curto acúmen, $<1 \mathrm{~mm}$ compr. Ginostêmio estipitado, 2-3 mm de compr., estipe $<1 \mathrm{~mm}$ compr.; anteras ca. $0,9 \mathrm{~mm}$ de compr. Cápsula subglobosa, 1,9-2,2 × 1,6 cm, curtamente rostrada, veia média do mericarpo proeminente, ca. $3 \mathrm{~mm}$ de espessura; sementes ovais, $5 \times 4$ $\mathrm{mm}$, côncavo-convexas, verrucosas, não-aladas, presença de rafe proeminente.

Material examinado: Linhares, Reserva Natural Vale, 20.III.2006, fl., D.A. Foli 5212 (CVRD; MBML; RB); Trilha do Pequi, 29.VI.2015, fr., E.J. Lírio 620 (MBML). Sooretama, Reserva Biológica de Sooretama, 9.VII.2014, fr., J. Freitas et al. 249 (MBML). Vila Valério, ES-358, distrito de Araribóia, 1.IX.2012, fl. e fr., J. Freitas \& A. M. Assis 180 (MBML).

Possui distribuição restrita à Mata Atlântica, sendo endêmica do Espírito Santo (BFG 2015) e registrada apenas para as Matas de tabuleiros (Fig. 19). Aristolochia subglobosa é representante de $A$. subsérie Anthocaulicae e é semelhante a $A$. bahiensis, porém difere desta pela base da folha não peltada ( $v s$. peltada em $A$. bahiensis) e pelo fruto subgloboso com 1,9-2,2 cm compr., com a veia média dos mericarpo proeminente, ca. $3 \mathrm{~mm}$ de espessura ( $v s$. cilíndrico, 2,9-3,8 cm de comprimento e a veia média do mericarpo não proeminente em $A$. bahiensis). Aristolochia subglobosa foi enquadrada pelos critérios da IUCN em Criticamente Ameaçada (CR) de acordo com os critérios da IUCN (2010, 2015): B1ab(i, iii) com $\mathrm{EOO}=71 \mathrm{~km}^{2}$.

18. Aristolochia tamnifolia (Klotzsch) Duch., Prodr.15 (1): 448. 1864 . Figs. 18a,b; 20a,b = Howardia tamnifolia Klotzsch, Monatsber. Königl. Preuss. Akad. Wiss. Berlin 620: 1859.

Trepadeiras. Caule suberoso. Ramos cilíndricos, entrenós 9,5-16 cm de compr. Pseudoestípulas ausentes. Pecíolo 2,1-4,7 cm de compr., glabro; lâmina amplamente oval, $7,1-13,5 \times 7,4-12,4 \mathrm{~cm}$, membranácea, face adaxial glabra, face abaxial pubérula, base cordada (sinus 0,5-2,2 cm de profundidade), não peltados, ápice acuminado a obtuso, venação primária basal 5(7). Inflorescências unifloras, não subtendidas por brácteas; Pedúnculo + ovário 2,1-6 cm de compr. Perianto glabro, verdeamarelado, externamente com estrias verdes; utrículo subgloboso a suborbicular, 1,6-1,9 × 
1,1-2,2 cm; siringe ca. $2,5 \mathrm{~mm}$, inequilátera; tubo funiforme, $1,4-2,5 \mathrm{~cm}$ compr. $\times 0,35-0,4$ cm (proximal) - 0,6 cm (distal) diâm.; limbo unilabiado, amplamente oval a oblongo, 1,2-1,9 $\times 0,7-1,5 \mathrm{~cm}$, convexo, verde claro com estrias vináceas delgadas no $2 / 3$ superior, fímbrias negras no ápice, base emarginada, não-peltada, margem inteira, ápice emarginado, terminando num curto acúmen, $<1 \mathrm{~mm}$ compr. Ginostêmio estipitado, ca. $5,5 \mathrm{~mm}$, estipe ca. $1 \mathrm{~mm}$ compr.; anteras oblongas, ca. 2,5 mm de compr. Cápsula cilíndrica, $5 \times 2,1$ $\mathrm{cm}$, veia média do mericarpo proeminente, $2 \mathrm{~mm}$ de espessura, rostrada, rostro ca. $1 \mathrm{~cm}$ de compr.; sementes amplamente ovais, $5 \times 4 \mathrm{~mm}$, côncavoconvexas, verrucosas, não aladas, rafe proeminente com duas excrescências laterais.

Material examinado: Águia Branca, Rochedo, propr. Arlindo Breda, 16.V.2007, fl., V. Demuner et al. 3892 (MBML). Boa Esperança, Pedra da Botelha, 12.IX.2009, fl., L. Kollmann \& E. Leme 11814 (MBML). Pancas, propr. Juliberto, 7.VII.2015, fr., J. Freitas et al. (MBML). Santa Teresa, estrada entre Pedra da Onça e Praça Oito, 10.XI.1998, fl., L. Kollmann et al 967 (MBML); 6.XI.2014, fr., J. Freitas \& L. Tonini 274 (MBML).

Material adicional examinado: BRASIL. BAHIA: Ilhéus, mirante após cidade de Ilhéus, sentido Itacarezinho, lado direito, Ilhéus, 26.X.2014, fl. e fr., E.J. Lirio et al. 773 (RB).
Apresenta distribuição para a Mata Atlântica e Cerrado, para os estados do Espírito Santo, Bahia, Alagoas e Sergipe (BFG 2015). No ES, é registrada para as Florestas Ombrófila Densa Montana e Estacional Semidecidual (Fig. 19). Aristolochia tamnifolia é representante de $A$. subsérie Hexandrae e morfologicamente similar a Aristolochia zebrina. Difere desta espécie pelo limbo amplamente oval a oblongo, com 1,2-1,9 $\mathrm{cm}$ comprimento, ornado de fímbrias no ápice (vs. estreitamente oval, 2,7-4 cm de comprimento, fímbrias ausentes em Aristolochia zebrina). Aristolochia tamnifolia pode ser considerada Em Perigo (EN) de acordo com os critérios da IUCN $(2010,2015)$ : B1B2ab(i, ii, iii) com $\mathrm{EOO}=2658$ $\mathrm{km}^{2}$ e AOO $=16 \mathrm{~km}^{2}$.

19. Aristolochia trilobata L., Sp. PI. 2: 960. 1753.

Figs. 18c,d; 20c,d

Trepadeiras. Caule suberoso não presente. Ramos cilíndricos, entrenós 5,6-18 cm compr. Pseudoestípulas presentes, orbiculadas, papiráceas, 1,7-2,7 × 1,6-2,4 cm. Pecíolo 3,4-6,5 cm de compr., glabro; lâmina profundamente trilobada, 5,3-14 × 6-13,5 cm, cartácea, face abaxial glabra, face adaxial pubescente, base levemente cordada (sinus 3-15 $\mathrm{mm}$ de profundidade) não peltada, lobo mediano oblongo a levemente rombóide,

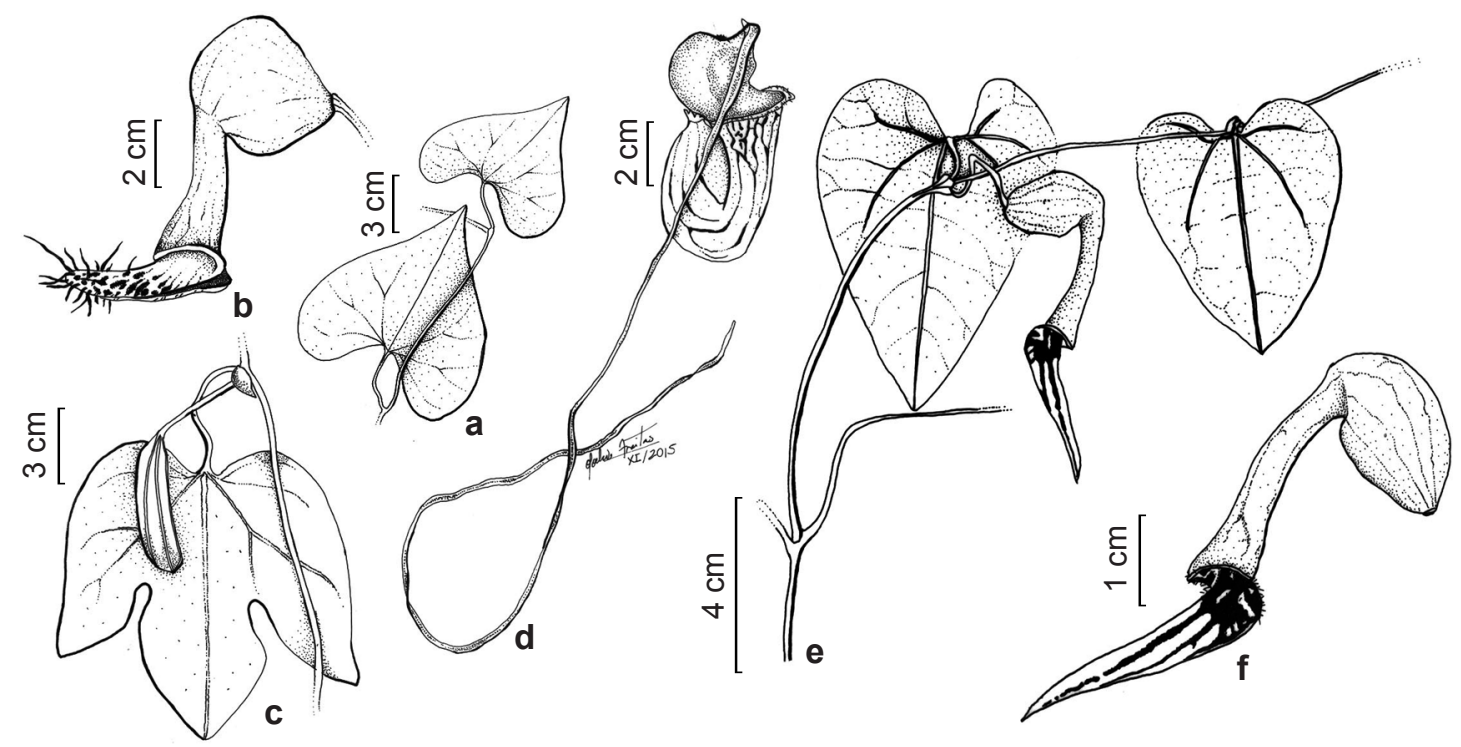

Figura 18 - a,b. Aristolochia tamnifolia - a. ramo; b. flor. c,d. Aristolochia trilobata - c. fruto; d. flor. e,f. Aristolochia zebrina - e. ramo florífero; f. flor.

Figure 18 - a,b. Aristolochia tamnifolia - a. branch; b. flower. c,d. Aristolochia trilobata - c. fruit; d. flower. e,f. Aristolochia zebrina - e. floriferous branch; f. flower. 
ápice acuminado a arredondado, 4,1-12,8 $\times$ 2,6-6 cm; lobos laterais elípticos a oblongos, ápice obtuso a arredondado, 3,8-8,3 × 1,6-2,8 $\mathrm{cm}$, venação primária basal 3(5). Inflorescências unifloras, não subtendidas por brácteas. Pedúnculo + ovário ca. 3,9-7,9 cm compr. Perianto glabro, bege com estrias vermelho-claras; utrículo amplamente obovado, 4-4,7 $\times 2,2-2,6 \mathrm{~cm}$, com 6 prolongamentos na base ca. $4 \mathrm{~mm}$; siringe ca. $6 \mathrm{~mm}$, inequilátera; tubo funiforme, $3,3-5,3 \mathrm{~cm}$ compr. $\times 1,1-1,3 \mathrm{~cm}$ (proximal) $-1,8-2,1 \mathrm{~cm}$ (distal) diâm.; limbo unilabiado, filiforme com duas expansões subcordadas na base, $6 \times 39 \mathrm{~cm}$ de compr., plano a levemente convexo, vermelho escuro, glabro, base subcordada, não peltada, margem levemente revoluta, ápice agudo, acúmen ausente. Ginostêmio estipitado, ca. 14 mm compr., estipite ca. $3 \mathrm{~mm}$ compr.; anteras lineares, ca. $7 \mathrm{~mm}$ de compr. Cápsula estreito-cilíndrica, $5,4-6,4 \times 2,2-2,6 \mathrm{~cm}$, veia média do mericarpo proeminente, ca. $1 \mathrm{~mm}$ de espessura, rostrada, rostro ca. $2 \mathrm{~mm}$ de compr.; sementes amplamente ovais, $6-7 \times 6 \mathrm{~mm}$, planas, face adaxial levemente verrucosa, face abaxial lisa, não aladas, rafe não proeminente.

Material examinado: Conceição da Barra, 10.V.1966, fl., A.P. Duarte 9772 (RB); Parque Estadual de Itaúnas, trilha principal após a sede do parque, 16.IX.2014, fl., J. Freitas \& L.A. Silva 255 (MBML); fl. e fr., J. Freitas \& L.A. Silva 257 (MBML; VIES). São Mateus, Uruçuquara, estrada para a BR-101, a $20 \mathrm{~km}$ da BR-101, 6.XI.2007, fr., C. Farney et al. 4822 (MBML; RB). Serra, margem do córrego Manguinhos, 23.III.2014, fr., A.M. Assis 4012 (MBML). Vila Velha, B. Jucu, 5.VII.1981, fl., B. Weinberg 642 (MBML);

Aristolochia trilobata tem ocorrência para a Amazônia, a Caatinga e a Mata Atlântica em diversos estados (BFG 2015). No ES, foi registrada apenas para a Restinga (Fig. 19), embora haja histórico de coleta para a Floresta Estacional Semidecidual. A espécie é representante de $A$. subsérie Hexandrae e é morfologicamente semelhante à Aristolochia hypoglauca devido ao seu grande limbo, porém é claramente distinta desta pelas suas folhas trilobadas (vs. amplamente

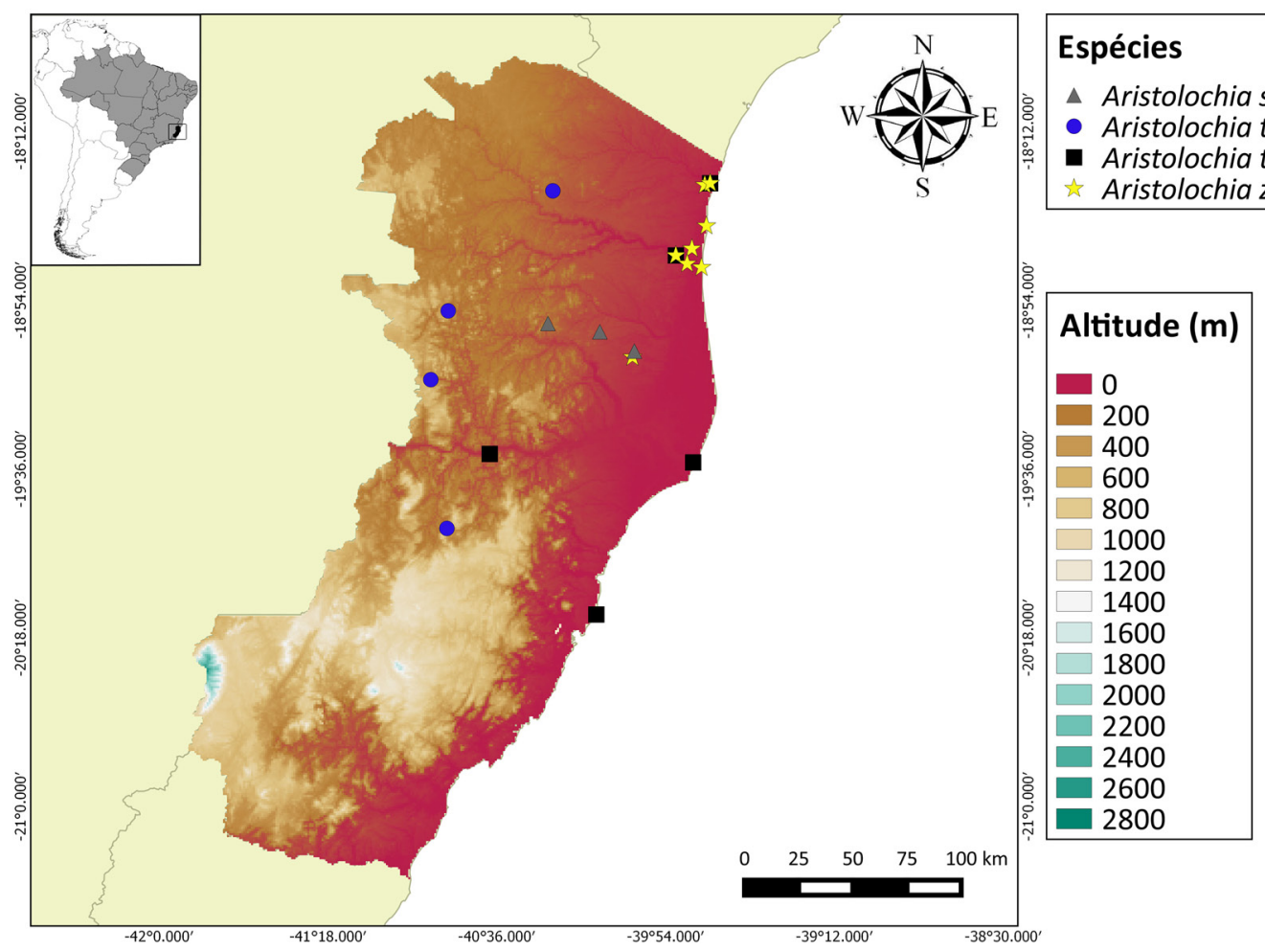

Figura 19 - Mapa de distribuição geográfica com camada altitudinal no estado do Espírito Santo - Aristolochia subglobosa ( $\mathbf{\Delta})$; Aristolochia tamnifolia $(\bullet)$; Aristolochia trilobata $(\boldsymbol{\square})$; Aristolochia zebrina $(\star)$.

Figure 19 - Map of geographic distribution with altitudinal layer in Espírito Santo state, Brazil -Aristolochia subglobosa ( $\mathbf{\Delta}) ;$ Aristolochia tamnifolia (•); Aristolochia trilobata $(\boldsymbol{\square})$; Aristolochia zebrina $(\star)$. 
oval em A. hypoglauca). Aristolochia trilobata pode ser considerada Menos preocupante (LC) de acordo com os critérios da IUCN (2015), devido à sua ampla distribuição nas restingas do ES.

20. Aristolochia zebrina J.Freitas \& F.González, Nordic Journal of Botany, 34(1): 54. 2016.

Figs. 18e,f; 20e-g

Ervas prostradas, raro trepadeiras. Caule suberoso ausente. Ramos cilíndricos, entrenós 7,5-19,5 cm de compr. Pseudoestípulas ausentes. Pecíolo 2,1-3,4 cm de compr.; lamina amplamente oval, 6,3-13,7 × 4,3-11 cm, papirácea, face adaxial glabra, abaxial pubescente a glabrescente, base cordada (sinus 1,3-2,5 cm de profundidade), não peltada, ápice agudo, venação primária basal
3(5). Inflorescências unifloras, não subtendidas por brácteas. Pedúnculo + ovário ca. $3,2 \mathrm{~cm}$ de compr.. Perianto glabro, bege com vináceo, frequentemente com estrias vináceas mais escuras externamente; utrículo elíptico, 1,7-2,1 $\times$ 1,1-1,4 cm, siringe ca. 2,2 mm, inequilátera; tubo funiforme, 2,6-2,9 cm compr. $\times 0,3 \mathrm{~cm}$ (proximal) - 1,3-1,4 cm (distal) diâm.; limbo unilabiado, 2,7$4 \times 1-1,4 \mathrm{~cm}$, convexo, o 1/5 basal esbranquiçado com manchas roxo-escuras e tricomas pretos, o restante, amarelo esbranquiçado com listras roxo-escuras, fímbrias ausentes, base emarginada, peltada, margem inteira, ápice agudo, terminando num curto acúmen, $<1 \mathrm{~mm}$ compr. Ginostêmio não estipitado, 4,1-4,9 mm compr.; anteras oblongas, 2,5 mm de compr. Cápsula amplamente cilíndrica,
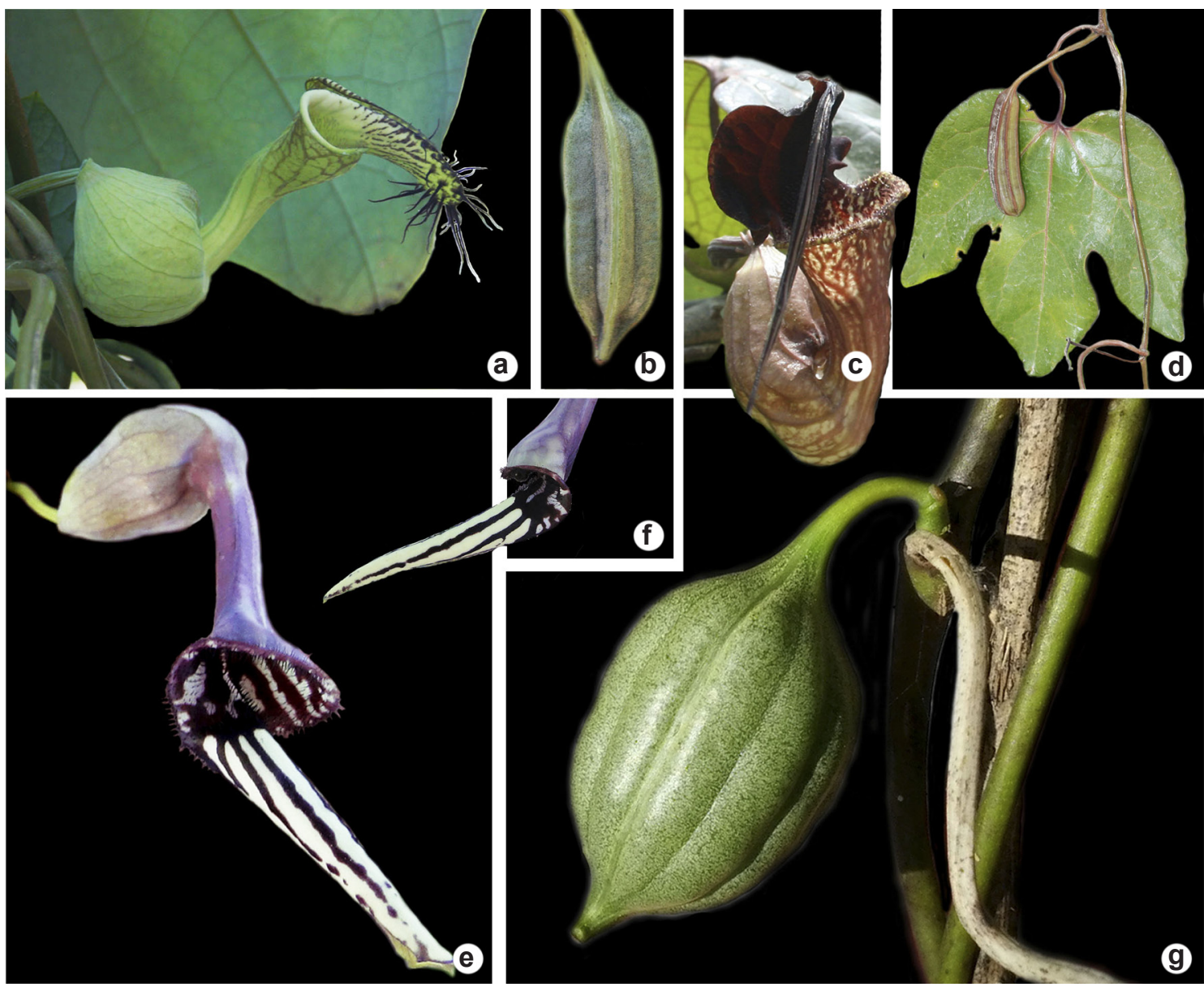

\section{,}


2,5-3,1 $\times 1,4-1,5 \mathrm{~cm}$, veia média do mericarpo proeminente, $<1 \mathrm{~mm}$ de espessura, rostrada, rostro ca. $4 \mathrm{~mm}$ de compr. Sementes amplamente ovais, $5,5 \times 4,5 \mathrm{~mm}$, concavo-convexas, face abaxial e marginal verrucosa, não-alada, rafe proeminente com duas excrescências laterais.

Material examinado: Conceição da Barra, APA de Conceição da Barra, área de pastagem próxima a fragmento florestal, 30.IX.2012, fl. e fr., J. Freitas \& A.M. Assis 181 (MBML); Parque Estadual de Itaúnas, em área degradada, 29.III.2000, fl., O.J. Pereira \& A.M. Assis 6052 (VIES); Trilha Alméscar, 8.VIII.2013, fr., W.O. Souza et al. 141 (VIES); 9.V.2014, fr., J. Freitas \& L.A. Silva 224 (VIES); 9.V.2014, fl. e fr., J. Freitas \& L.A. Silva 226 (VIES); Trilha da Restinga, 19.V.2014, fl. e fr., J. Freitas et al. 228 (VIES); 22.III.2014, fl., $A$. Alves-Araújo et al. 1640 (VIES); 6.IX.2014, fr., W.O. Souza et al. 382 (VIES). Itaúnas, Mata de restinga sobre cordão arenoso próximo de uma área entre cordões dominada por Montrichardia, área atrás da fazendo Jequitaia, 31.V.2009, fl., A.O. Giaretta et al. 536 (VIES); mata seca de restinga sobre cordão arenoso, próximo de uma área entre cordões alagada, dominada por Montrichardia, área atrás da fazenda Jequitaia, 16.XII.2008, fl., M.M. Monteiro \& A.G. Oliveira 131 (VIES); área 126 da Aracruz Celulose S.A., Restinga, 27.II.1992, fl., O.J. Pereira 2904 (VIES); área 157 da Aracruz Celulose S.A., restinga, mata seca, 27.III.1992, fl., O.J. Pereira 3247 (VIES); área 135 da Aracruz Celulose S.A., restinga, mata seca, 9.VI.1992, fl., O.J. Pereira 3401 (VIES). Linhares, Reserva Natural Vale, 5.IV.2006, fl., G.Q. Freire 19 (CVRD, ESA); 20.X.1998, f1., D.A. Folli 3267 (CVRD, MBML, RB); 24.V.2001, f1., D.A. Folli 3932 (CVRD, MBML, RB); 20.IV.1983, fl. e fr., A.L. Peixoto \& H.C. de Lima 1739 (RB, RBR). São Mateus, Bairro Liberdade, 6.III.2008, fl., O.J. Pereira et al. 7594 (VIES); próximo ao Hospital Roberto Silvares, 27.II.2007, fr., F.C. Teotônio 13 (VIES). Guriri, próximo ao projeto Tamar, 6.III.2008, fl., M.M. Monteiro et al. 214 (VIES); Bairro Quadrado, fundo do campus do CEUNES, 30.XI.2011, f1., A.O. Giaretta et al. 1121 (VIES).

Possui distribuição restrita à Mata Atlântica, endêmica para o Espírito Santo. Os registros são majoritariamente provenientes das Restingas (Fig. 19), porém com ocorrência nos Tabuleiros. Aristolochia zebrina pertente à $A$. subsérie Hexandrae e é morfologicamente similar a A. tamnifolia, diferindo da mesma pelo limbo estreitamente oval, 2,7-4 cm compr. e fímbrias ausentes no limbo ( $v s$. amplamente oval a oblongo, 1,2-1,9 cm compr. e ornado de fímbrias no ápice do limbo em A. tamnifolia). Aristolochia zebrina pode ser considerada Em Perigo (EN) de acordo com os critérios da IUCN $(2010,2015)$ : B1b(i, iii) com $\mathrm{EOO}<592 \mathrm{~km}^{2}$.

\section{Agradecimentos}

Aos curadores dos herbários visitados em especial a Helio Q. Boudet Fernandes, curador do MBML, por permitir os estudos na coleção durante toda a execução do trabalho. A Lucas de Almeida Silva, Lorena Tonini, Jaquelini Luber, Elton John de Lírio, Michel Ribeiro e a toda equipe do Laboratório de Sistemática e Genética Vegetal (SGV) da UFES/CEUNES, o apoio durante as coletas. A Manoel Santos, o apoio no cultivo das espécies no INMA. A André M. de Assis, Elton John de Lírio, Fernando C. Campos Neto, Idimá Gonçalves, Lucas de Almeida Silva e Michel Ribeiro, por ceder o uso das fotos de algumas espécies. A Tatiana Tavares Carrijo, Marccus Alves e Elton John de Lírio, as valiosas sugestões ao manuscrito. À Fundação Capes, a concessão da bolsa ao primeiro autor.

\section{Referências}

Abreu IS \& Giulietti AM (2016a) Flora da Bahia: Aristolochiaceae. Sitientibus série Ciências Biológicas 16: 1-25.

Abreu IS \& Giulietti AM (2016b) Aristolochia brunneomaculata, a new threatened species of Aristolochiaceae from the Atlantic Forest in Bahia, Brazil. Sitientibus série Ciências Biológicas 16: 1-6.

Ahumada LZ (1967) Revisión de las Aristolochiaceae argentinas. Opera Lilloana 16: 1-148.

APG IV - The Angiosperm Phylogeny Group (2016) An update of the Angiosperm Phylogeny Group classification for the orders and families of flowering plants. Botanical Journal of the Linnean Society 181: 1-20.

Araújo AAM (2013a) Aristolochiaceae Juss. na Mata Atlântica do Nordeste, Brasil. Dissertação de Mestrado. Univesidade Federal do Pernambuco, Recife. 74p.

Araújo AAM (2013b) Aristolochiaceae. In: Prata APN, Amaral MCE, Farias MCV \& Alves MV (org.) Flora de Sergipe 1: 96-99.

Araújo AAM \& Alves M (2013) Aristolochia setulosa (Aristolochiaceae), a new species from northeastern Brazil. Brittonia 65: 301-304.

Bachman S, Moat J, Hill AW, de la Torre J \& Scott B (2011) Supporting Red List threat assessments with GeoCAT: geospatial conservation assessment tool. In: Smith V \& Penev L (eds.) e-Infrastructures for data publishing in biodiversity science. (Version BETA)*. ZooKeys 150: 117-126.

BFG - The Brazil Flora Group (2015) Growing knowledge: an overview of seed plant diversity in Brazil. Rodriguésia 66: 1085-1113.

Brasil (2006) O corredor central da Mata Attântica: uma nova escala de conservação da biodiversidade. 
Ministério do Meio Ambiente, Conservação Internacional e Fundação SOS Mata Atlântica, Brasília. 46p.

Bridson D \& Forman L (1998) The Herbarium Handbook. Royal Botanical Garden, Lubrecht \& Cramer Ltd., Richmond. 348p.

Capellari Jr L (1991) Espécies de Aristolochia L. (Aristolochiaceae) ocorrentes no estado de São Paulo. Dissertação de Mestrado. Universidade Estadual de Campinas, Campinas. 205p.

Conservation International do Brasil, Fundação SOS Mata Atlântica, Fundação Biodiversitas, Instituto de Pesquisas Ecológicas, Secretaria do Meio Ambiente do Estado de São Paulo, SEMAD/Instituto Estadual de Florestas - MG (2000) Avaliação e ações prioritárias para a conservação da biodiversidade da Mata Atlântica e Campos Sulinos. MMA/SBF, Brasília. 40p.

Dutra VF, Alves-Araújo A \& Carrijo TT (2015) Angiosperm checklist of Espírito Santo: using electronic tools to improve the knowledge of an Atlantic Forest biodiversity hotspot. Rodriguésia 66: 1145-1152.

Freitas J, Lírio EJ \& González F (2013a) Aristolochia bahiensis (Aristolochiaceae) reaches Espírito Santo: range extension and first description of capsules and seeds. Boletim do Museu de Biologia Mello Leitão 32: 5-11.

Freitas J, Lírio EJ \& GonzalézF (2013b)Anew cauliflorous species of Aristolochia (Aristolochiaceae) from Espírito Santo, Brazil. Phytotaxa 124: 51-59.

Freitas J, Lírio EJ \& Gonzaléz F (2014) Aristolochia assisii, a new neotenic species of Aristolochiaceae from Espírito Santo and Bahia, Brazil. Phytotaxa 163: 262-268.

Freitas J, Lírio EJ, González F \& Alves-Araújo A (2016) Aristolochia zebrina, a new species of Aristolochiaceae from southeastern Brazil. Nordic Journal of Botany 34: 54-59.

Freitas J, Lírio EJ, Peixoto M, Guimarães EF \& Alves-Araújo A (2017) Aristolochia insolita (Aristolochiaceae), a New Species from Rio de Janeiro, Brazil. Systematic Botany 42: 169-174.

Fundação SOS Mata Atlântica \& INPE (2014) Atlas dos remanescentes florestais da Mata Atlântica. Período 2012-2013. Fundação SOS Mata Atlântica, São Paulo. 61p.

Gallindo-Leal C \& Câmara IB (2005) Mata Atlântica: biodiversidade, ameaças e perspectivas. Traduzido por Edma Reis Lamas. Fundação SOS Mata Atlântica, São Paulo - Conservação Internacional, Belo Horizonte. 471p.

Garbin ML, Saiter FZ, Carrijo TT \& Peixoto AL (2017) Breve histórico e classificação da vegetação capixaba. Rodriguésia 68: 1883-1894.

GBIF - Global Biodiversity Information Facility (2015) Disponível em <http://www.gbif.org > . Acesso em 16 outubro 2015.
González F (1990) Flora de Colombia. Aristolochiaceae. Monografia $\mathrm{n}^{\circ} \mathrm{12}$. Universidad Nacional de Colombia, Instituto de Ciencias Naturales, Bogotá. 184p.

González F (1991) Notes on the systematics of Aristolochia subsect. Hexandrae. Annals Missouri Botanical Garden 78: 497-503.

González F (1994) Aristolochiaceae. Flora of Ecuador. In: Harling GW \& Andersson L (eds.) Flora of Ecuador. Monograph $\mathrm{n}^{\mathrm{o}}$ 51. Council for Nordic Publications in Botany, Copenhagen. $42 \mathrm{p}$.

González F (1997) Hacia una fillogenia de Aristolochia y sus congéneres neotropicales. Caldasia 19: 115-130.

González F (1998) Two new species of Aristolochia (Aristolochiaceae) from Brazil and Peru. Brittonia 50: 5-10.

González F (2000) A new species of Aristolochia (Aristolochiaceae) from Bahia, Brazil. Novon 10: 371-374.

González F (2011) A new pseudostipule-bearing species of Aristolochia (Aristolochiaceae) from Bahia and Espírito Santo, Brazil. Brittonia 63: 430-435.

González F (2012) Florística y sistemática filogenética innecesariamente disyuntas: el caso de Aristolochia, Euglypha y Holostylis. Revista de la Academia Colombiana de Ciencias Exactas, Físicas y Naturales 36: 193-202.

Harris JG \& Harris MW (2001) Plant identificacion terminology: an illustrated glossary. $2^{\text {nd }}$ ed. Spring Lake Publishing, Spring Lake. 206p.

Hoehne FC (1927) Monographia illustrada das aristolochiaceas brasileiras. Memórias do Instituto Oswaldo Cruz 20: 67-175.

Hoehne FC (1942) Aristolochiaceas. Instituto de Botânica, São Paulo. Flora Brasílica 15: 1-141, t. 1-123.

Hickey LJ (1973) Classification of the architecture of dicotyledonous leaves. American Journal of Botany 60: 17-33.

IUCN (2010) Guidelines for application of IUCN Red List criteria at regional and national levels. Version 4.0. Disponível em <http://www. iucnredlist.org $>$. Acesso em 1 agosto 2015.

IUCN (2015) Guidelines for using the IUCN Red List categories and criteria. Version 11. Prepared by the standards and petitions subcommittee. Disponível em <http://www.iucnredlist.org/ documents/RedListGuidelines.pdf $>$. Acesso em 1 agosto 2015 .

Kollmann LJC, Fontana AP, Simonelli M \& Franga CN (2007) As Angiospermas ameaçadas de extinção no estado do Espírito Santo. In: Simonelli M \& Fraga CN (orgs.) Espécies da flora ameaçadas de extinção no estado do Espírito Santo. IPEMA, Vitória.146p. 
Lani JL, Resende M, Rezende SB \& Feitosa LR (2008) Atlas dos ecossistemas do Espírito Santo. UFV, Viçosa. 504p.

Martini AMZ, Fiaschi P, Amorim AM \& Paixão JL (2007) A hot-point within a hot-spot: a high diversity site in Brazil's Atlantic Forest. Biodiversity and Conservantion 16: 3111-3128.

Mittermeier RA, Gil PR, HoVmann M, Pilgrim J, Brooks J, Mittermeier CG, Lamourux J \& Fonseca GAB (2004) Hotspots revisited: earth's biologically richest and most endangered terrestrial ecoregions. Cemex, Washington DC. $392 p$.

Quantum GIS Development Team (2015) Quantum GIS Geographic Information System. Open Source Geospatial Foundation Project.
Disponível em $<$ http://qgis.osgeo.org $>$. Acesso em 1 agosto 2015.

Nascimento DS (2008) Estudo taxonômico da família Aristolochiaceae Juss. do Sul do Brasil. Dissertação de Mestrado. Universidade Federal do Paraná, Curitiba. 123p.

SpeciesLink (2015) Ferramenta desenvolvida pelo CRIA. Disponível em <http://www.splink.org.br $>$. Acesso em 16 outubro 2015.

Thiers B [continuaente atualizado] Index Herbariorum: a global directory of public herbaria and associated staff. New York Botanical Garden's Virtual Herbarium. Disponível em $<$ http://sweetgum.nybg. org/ih./>. Acesso em 16 outubro 2015.

WHO - World Health Organization (2004) Aristolochic acid. Pharmaceuticals Newsletter 5: 1.

\section{Lista de exsicatas}

Alves-Araújo A 1640 (20). Assis AM 1461 (6), 2327 (2), 2597 (2), 4012 (19). Bausen E 10 (12). Brito RC 218 (15). Castro RM 752 (4). Coelho PJ 38 (11). Costa IG 128 (19). Demuner V 1008 (10), 2034 (14), 2119 (10), 3517 (10), 3892 (18), 4498 (13), 4834 (10). Didonet AA 05 (7). Duarte AP 3639 (4), 9772 (19). Farias GL 602 (16). Farney C 4822 (19). Foli DA 3267 (20), 3932 (20), 5212 (17). Fontana AP 1345 (11). Forzza RC 5403 (5). Fraga CN 2476 (5). Freire GQ 19 (21). Freitas J 02 (11), 6 (3), 160 (3), 180 (17), 181 (20), 188 (11), 197 (11), 224 (20), 226 (20), 228 (20), 249 (17), 252 (3), 253 (3), 255 (19), 257 (19), 258 (5), 260 (16), 274 (18), 283 (3), 286 (3), 292 (13), 295 (10), 350 (1), 360 (6), 361 (16), 363 (10), 367 (14), 368 (16), 369 (16), 415 (6), 416 (8), 417 (10), 422 (13), 431 (9), 432 (7), 433 (1). Giaretta AO 536 (20), 1121 (20). Hatschbach G 59774 (4). Hencker C 61 (9). Kautsky RA 832 (3), 963 (12). Kollmann L 967 (18), 2559 (6), 3325 (15), 3537 (10), 4495 (11), 7468 (11), 8749 (11), 9484 (5), 9762 (5), 10162 (11), 11052 (12), 11814 (18), 12176 (3). Kuhlmann JG 238 (11). Leoni L 7099 (15). Lírio EJ 553 (8), 620 (17), 683 (11), 773 (17), 1440 (6), 1441 (9), 1442 (9). Magnago LFS 803 (10), 1221 (11). Martins GN 102 (2). Monteiro MM 131 (20), 214 (20). Nunes TS 1763 (11). Peixoto AL 1739 (20). Pena NTL 269 (15). Pereira OJ 2904 (20), 3247 (20), 3401 (20), 6052 (20), 7594 (20). Queiroz LP 12743 (8). Rosa LV 166 (2), 204 (2). Rossini J 584 (11). Santos R 80 (2). Senra LC 26 (8). Simonelli M 1497 (6). Souza WO 141 (20), 382 (20). Teotônio FC 13 (20). Vieira LA s.n. (MBML 23635) (12). Weinberg B 642 (19). 
